Additional Perspectives articles for Influenza: The Cutting Edge book collection are available at http://perspectivesinmedicine.cshlp.org/cgi/collection/influenza_the_cutting_edge.

\title{
Influenza Hemagglutinin Structures and Antibody Recognition
}

\author{
Nicholas C. $\mathrm{Wu}^{1}$ and Ian A. Wilson ${ }^{1,2}$ \\ ${ }^{1}$ Department of Integrative Structural and Computational Biology, The Scripps Research Institute, La Jolla, \\ California 92037, USA \\ ${ }^{2}$ The Skaggs Institute for Chemical Biology, The Scripps Research Institute, La Jolla, California 92037, USA \\ Correspondence: wilson@scripps.edu
}

Hemagglutinin (HA) is most abundant glycoprotein on the influenza virus surface. Influenza $\mathrm{HA}$ promotes viral entry by engaging the receptor and mediating virus-host membrane fusion. At the same time, HA is the major antigen of the influenza virus. HA antigenic shift can result in pandemics, whereas antigenic drift allows human circulating strains to escape herd immunity. Most antibody responses against HA are strain-specific. However, antibodies that have neutralizing activities against multiple strains or even subtypes have now been discovered and characterized. These broadly neutralizing antibodies (bnAbs) target conserved regions on $\mathrm{HA}$, such as the receptor-binding site and the stem domain. Structural studies of such bnAbs have provided important insight into universal influenza vaccine and therapeutic design. This review discusses the HA functions as well as HA-antibody interactions from a structural perspective.

Influris nfluenza viruses are classified based on their antigenicity, which is determined by their surface glycoproteins. Four types of influenza viruses, $\mathrm{A}, \mathrm{B}, \mathrm{C}$, and $\mathrm{D}$, have been isolated and characterized. Influenza $\mathrm{A}$ and $\mathrm{B}$ viruses have two surface glycoproteins, hemagglutinin (HA) and neuraminidase (NA), whereas influenza C and $D$ viruses have only one surface glycoprotein, hemagglutinin-esterase fusion (HEF). Based on the antigenicity of $\mathrm{HA}$ and $\mathrm{NA}$, influenza A viruses are further classified into subtypes. There are 18 known HA subtypes (H1-H18) and 11 known NA subtypes (N1-N11). HA subtypes are further divided into two groups. Group $1 \mathrm{HA}$ includes $\mathrm{H} 1, \mathrm{H} 2, \mathrm{H} 5, \mathrm{H} 6, \mathrm{H} 8, \mathrm{H} 9, \mathrm{H} 11$, $\mathrm{H} 12, \mathrm{H} 13, \mathrm{H} 16, \mathrm{H} 17$, and $\mathrm{H} 18$, whereas group $2 \mathrm{HA}$ includes $\mathrm{H} 3, \mathrm{H} 4, \mathrm{H} 7, \mathrm{H} 10, \mathrm{H} 14$, and H15.
Both influenza A and B viruses infect humans and can cause severe illness or death. In contrast, influenza $\mathrm{C}$ virus only causes mild symptoms in most cases. Human infection with influenza D virus has not been observed. Therefore, most influenza research has been focused on influenza A and $B$ viruses. A main difference between influenza $A$ and $B$ viruses is that influenza $B$ virus is only found in humans, whereas the primary natural reservoir for influenza A virus is aquatic birds; these avian viruses can give rise to new pandemic viruses in humans through reassortment with human and swine viruses. As a result, influenza A virus usually receives more attention and has been studied more extensively.

The surface of influenza virions is dominated by HA, which outnumbers NA by five- to 10 -

Editors: Gabriele Neumann and Yoshihiro Kawaoka

Additional Perspectives on Influenza: The Cutting Edge available at www.perspectivesinmedicine.org

Copyright (C) 2020 Cold Spring Harbor Laboratory Press; all rights reserved; doi: 10.1101/cshperspect.a038778

Cite this article as Cold Spring Harb Perspect Med 2020;10:a038778 
N.C. Wu and I.A. Wilson

fold (Harris et al. 2006; Hutchinson et al. 2014). HA confers upon influenza virus the ability to agglutinate red blood cells, which enables rapid quantification of influenza virus (hemagglutination assay) as well as the virus-neutralizing capacity of antibodies and sera (hemagglutination inhibition assay) (Hirst 1942). The ability of HA to agglutinate red blood cells can be attributed to its receptor binding function. HA engages sialylated glycan receptors on host cells to initiate viral entry (Burnet and Stone 1947; Stone 1948). HA also carries the machinery for membrane fusion (Maeda and Ohnishi 1980). HA is a homotrimer consisting of a globular head domain that resides atop a membrane-proximal stem domain (Fig. 1A). Its structure was first reported in 1981 (Wilson et al. 1981), which made it possible to study the structure-function relationships of HA. In a back-to-back article, the major antigenic sites on the $\mathrm{H} 3 \mathrm{HA}$ were also described for the first time (Wiley et al. 1981). Characterization of an HA-peptide antibody in 1984 led to the identification of the HA-tag (Wilson et al. 1984), which is a linear epitope consisting of nine amino acids that is used extensively in protein purification and labeling.
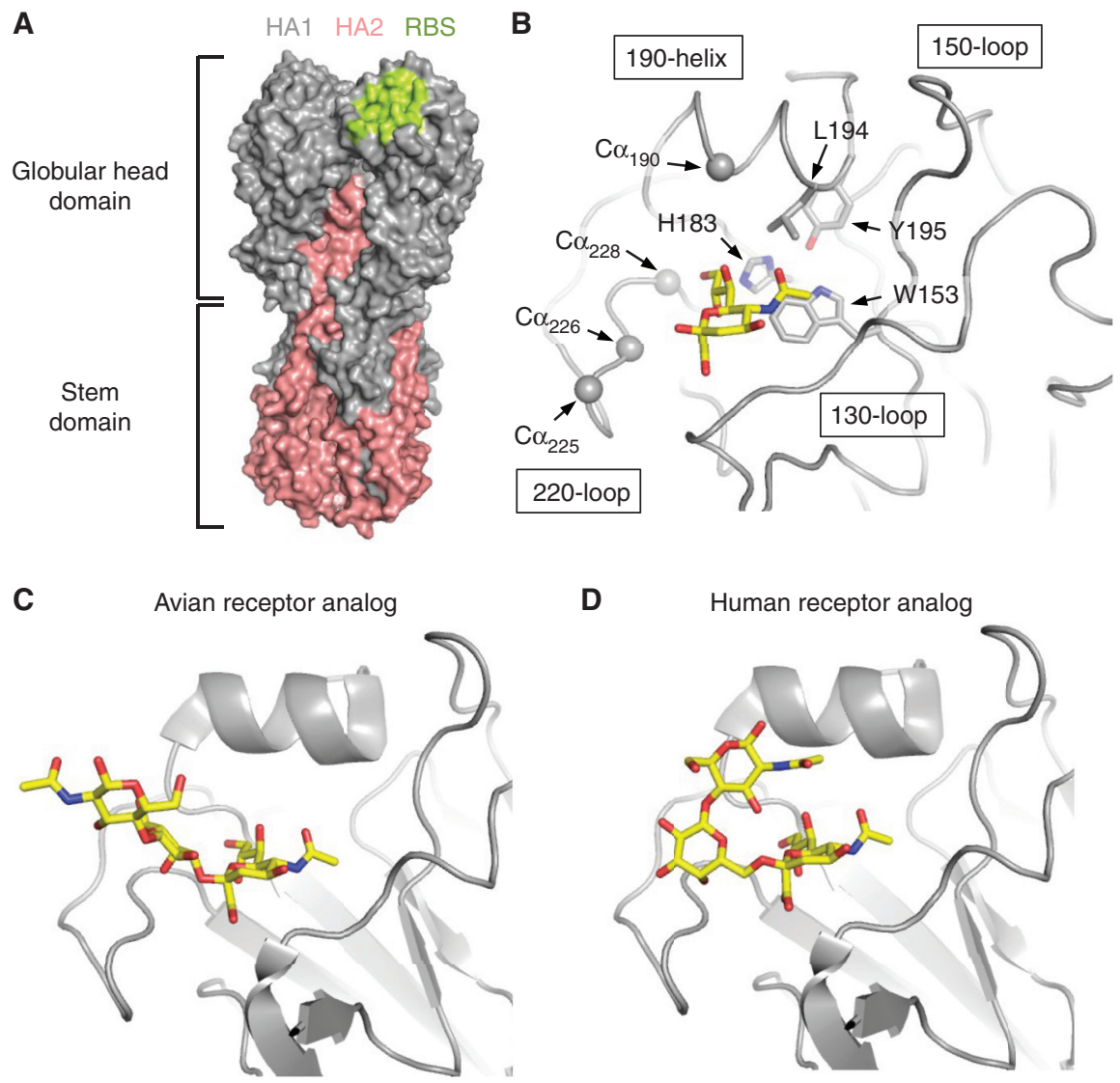

Figure 1. Hemagglutinin (HA) structures and receptor-binding site (RBS). (A) Structure of trimeric HA. The location of the RBS is shown in lime on the HA structure. HA1 is shown in gray and HA2 in salmon. The globular head domain sits on top of the stem domain. (B) The major structural elements, namely 130-loop, 150-loop, 190helix, and 220-loop, of the HA RBS are shown. Highly conserved residues W153, H183, L194, and Y195 are shown in stick representation. The alpha carbons (Cos) of HA1 residues 190, 225, 226, and 228, which are involved in the $\mathrm{H} 1, \mathrm{H} 2$, and $\mathrm{H} 3$ receptor-specificity switch, are shown in sphere representations. (C) Avian-type receptor ( $\alpha 2,3$-linked sialic acid) binds to HA with an extended configuration (Xu et al. 2012). (D) Human-type receptor ( $\alpha 2,6$-linked sialic acid) binds to HA with a folded-back configuration (Xu et al. 2012). 
Despite being extremely useful as a research tool, the HA-tag epitope is not clinically relevant because it is located in the subunit interface of $\mathrm{HA}$, which is not accessible in the native form of HA. The structure of a neutralizing antibody in complex with HA was first reported in 1995 (Bizebard et al. 1995), which provided important insights into the molecular mechanism of how HA is recognized by the adaptive humoral immune system.

As a major antigen of influenza virus, HA constantly evolves to escape herd immunity arising from natural infection and vaccination, while still preserving its functionality (Wu and Wilson 2017). That is why the various components of the seasonal influenza vaccine need to be annually reviewed and updated, when necessary. Most antibodies elicited by seasonal influenza vaccines are strain-specific and the virus can readily escape such antibodies. Nonetheless, many broadly neutralizing antibodies (bnAbs) against HA have been identified and characterized in the past decade (Wu and Wilson 2018), which has enabled structural-based design of universal influenza vaccine candidates (Impagliazzo et al. 2015; Yassine et al. 2015). Understanding the structural biology of HA has been accelerating in recent years, in large part owing to the technical advances in X-ray crystallography (Garman 2014) as well as cryogenic electron microscopy (cryo-EM) (Nogales 2016). This review will describe the biology of HA and antibodies against HA from a structural perspective. $\mathrm{H} 3$ numbering is used for HAs throughout, unless indicated otherwise.

\section{RECEPTOR BINDING AND SPECIFICITY OF HEMAGGLUTININ}

Each protomer of HA contains a membranedistal receptor-binding site (RBS) in the globular head domain that binds to sialylated glycan receptors on the host cell surface (Fig. 1A) (Weis et al. 1988). Nevertheless, it should be noted that the $\mathrm{H} 17$ and $\mathrm{H} 18$ subtypes, which are found only in bats, do not bind to sialic acids and are the exceptions (Sun et al. 2013; Tong et al. 2013; Zhu et al. 2013b). Instead, H17 and H18 HAs utilize the major histocompatibility complex class II (MHC-II) molecule as host receptor (Karakus et al. 2019). The HA RBS is composed of the 130-loop, 150-loop, 190-helix, and 220loop, named after their relative positions on the HA amino-acid sequence. Several key residues that interact with sialic acid are conserved across influenza A and B HAs (Wang et al. 2007). These include W153, H183, L194, and Y195 (Fig. 1B). However, major structural variations of the HA RBS can also be observed in naturally circulating strains. Examples include a single residue insertion in the 130-loop of some strains from $\mathrm{H} 1$ and $\mathrm{H} 5$ subtypes and all strains from H6 and H10 subtypes (Lee et al. 2012), a tworesidue insertion in the 150-loop of $\mathrm{H} 7, \mathrm{H} 10$, and H15 subtypes (Tzarum et al. 2017), and an eight-residue deletion in the 220-loop of multiple H7N2 strains (Suarez et al. 1999; Yang et al. 2010).

The receptor specificity for avian influenza viruses is $\alpha 2,3$-linked sialic acid (avian-type receptor), whereas for human influenza viruses it is $\alpha 2,6$-linked sialic acid (human-type receptor). When binding to $\mathrm{HA}, \alpha 2,3$-linked sialic acid typically displayed an extended configuration (Fig. 1C), whereas $\alpha 2,6$-linked sialic acid typically displayed a folded-back configuration (Fig. 1D) (Shi et al. 2014). This folded-back conformation is in fact the most energetically stable conformation of $\alpha 2,6$-linked sialic acid in sialosides in their unbound form (Sabesan et al. 1991). Switching the receptor specificity from $\alpha 2,3$-linked sialic acid to $\alpha 2,6$-linked sialic acid is required for avian influenza viruses to cause human pandemics and for transmission, as assessed in an animal model between ferrets (Tumpey et al. 2007; Pappas et al. 2010; Roberts et al. 2011). The structural mechanisms for the receptor specificity switch are well-characterized for $\mathrm{H} 1, \mathrm{H} 2$, and $\mathrm{H} 3$, all of which are associated with known influenza pandemics-the Spanish flu (H1N1) pandemic in 1918, the Asian flu (H2N2) pandemic in 1957, the Hong Kong flu (H3N2) pandemic in 1968, and the most recent swine flu (H1N1) pandemic in 2009. All avian $\mathrm{H} 1, \mathrm{H} 2$, and $\mathrm{H} 3 \mathrm{HAs}$ predominately encode Glu, Gly, Gln, and Gly at residues 190, 225, 226 , and 228 , respectively. $\mathrm{H} 1$ requires a pair 
of mutations E190D/G225D to switch receptor specificity from $\alpha 2,3$-linked sialic acid to $\alpha 2,6$ linked sialic acid (Matrosovich et al. 1997; Glaser et al. 2005; Stevens et al. 2006; Tumpey et al. 2007), whereas $\mathrm{H} 2$ and $\mathrm{H} 3$ require a different pair Q226L/G228S (Rogers et al. 1983; Connor et al. 1994; Pappas et al. 2010; Xu et al. 2010). Recent human H3N2 viruses have further evolved a receptor specificity favoring long $\alpha 2,6$ sialylated glycans with several $N$-acetyllactosamine (LacNAc) repeats (Peng et al. 2017). Consistently, the receptor-binding mode has subtly evolved in recent human H3N2 viruses (Lin et al. 2012; Wu et al. 2018a).

Other subtypes including H5, H6, H7, H9, and $\mathrm{H} 10$ are occasionally transmitted to humans. To date, naturally circulating strains from these subtypes have not acquired the receptor specificity to $\alpha 2,6$-linked sialic acids and, hence, are not able to transmit among humans. Nonetheless, studies have explored the possibility of switching receptor specificity from $\alpha 2,3$ linked sialic acid to $\alpha 2,6$-linked sialic acid in different subtypes that may have pandemic potential. In 2013, two studies independently adapted $\mathrm{H} 5 \mathrm{~N} 1$ strains to acquire transmissibility among ferrets, which is a commonly used mammalian model for influenza transmission (Herfst et al. 2012; Imai et al. 2012). In both studies, mutations in the HA RBS were observed in the ferret-transmissible H5N1 strains. Common mutations in the HA RBS that were identified by both studies include Q226L and a loss of glycosylation site at residue 158 (Herfst et al. 2012; Imai et al. 2012). Follow-up studies showed that those mutations are important for $\mathrm{H} 5 \mathrm{HA}$ to switch receptor specificity from $\alpha 2,3$-linked sialic acid to $\alpha 2,6$-linked sialic acid ( $\mathrm{Lu}$ et al. 2013; Xiong et al. 2013; de Vries et al. 2014). Those studies provoked the National Institutes of Health (NIH) to declare a pause on certain influenza gain-of-function studies in 2014 (Casadevall and Imperiale 2014), which was then lifted in late 2017. How other HA subtypes switch receptor specificity from $\alpha 2,3$-linked sialic acid to $\alpha 2,6$-linked sialic acid has also been studied. Different subtypes appear to require different sets of mutations to switch specificity toward $\alpha 2,6$-linked sialic acid-Q226L/
G228S for H4 HA (Song et al. 2017), G225D for H6 HA (de Vries et al. 2017b), V186G/K193T/ G228S, V186K/K193T/G228S or V186N/ N224K/G228S for H7 HA (de Vries et al. 2017a), and K158aA/D193T/Q226L/G228S for H10 HA (Tzarum et al. 2017) ("158a" indicates the insertion of an amino acid after position 158). Because of the structural variability of the RBS in different HA subtypes, it is not surprising that the mutational requirements for switching receptor specificity are different for different subtypes.

\section{HEMAGGLUTININ-MEDIATED MEMBRANE FUSION}

Besides engaging the receptor, HA also mediates virus-host membrane fusion, which is essential for viral entry. Comparing the HA structures between prefusion and postfusion conformations shows that HA has to undergo large conformational rearrangements to promote virus-host membrane fusion (Bullough et al. 1994; Chen et al. 1999). Such a large conformational change is only possible after proteolytic processing of the HA trimer. During protein translation, HA trimer is synthesized as a single polypeptide chain (HA0). HA0 is then cleaved by host cell proteases to become mature HA, which consists of HA1 and HA2 subunits that remain cross-linked via a single disulfide bond (Fig. 2A). The mature HA, but not HA0, is fusion-competent. The cleavage site is a surface loop in the stem domain. The amino-acid sequence of the cleavage site varies (Böttcher-Friebertshauser et al. 2013). Although most strains carry a monobasic cleavage site, some strains carry a polybasic cleavage site. Monobasic cleavage site can be processed by proteases such as plasmin (Lazarowitz and Choppin 1975), factor Xa (Gotoh et al. 1990), tryptase Clara (Kido et al. 1992), HAT (Böttcher et al. 2006), and TMRPSS2 (Böttcher et al. 2006). The tissue tropism of influenza virus is strongly influenced by these proteases, which are only present in a limited number of tissues, such as the respiratory or intestinal tract. In contrast, polybasic cleavage sites, mainly found in avian viruses, can be processed by furin, which is ubiquitously expressed. 


\section{A}

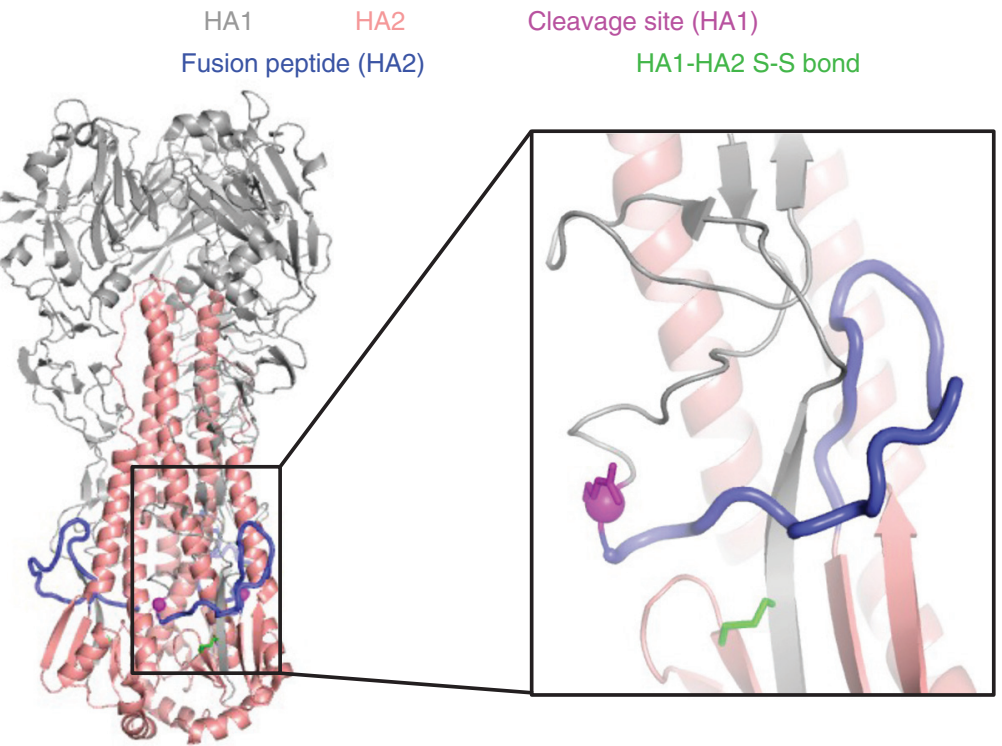

B

Prefusion

Postfusion
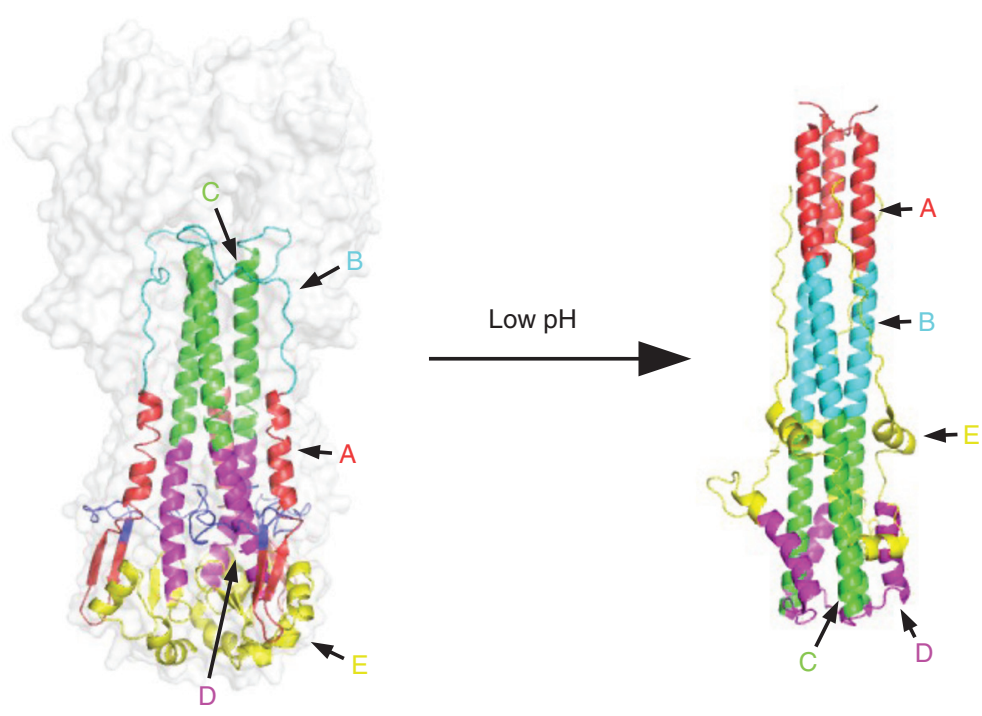

Figure 2. Fusion machinery of hemagglutinin (HA). (A) Several important structural features in the stem domain, including the cleavage site (carboxy-terminal Arg of HA1), fusion peptide (amino-terminal region of HA2), and the disulfide bond that links HA1 and HA2, are highlighted. (B) The structural rearrangements of the HA2 between prefusion and postfusion conformations are shown (Chen et al. 1999).

Therefore, influenza strains with polybasic cleavage site are typically highly pathogenic. This proteolytic processing of HA does not induce substantial conformational changes, as shown by the structural comparison of the precursor HA0 (uncleaved form) and mature HA (cleaved form), which are almost identical (Chen et al. 1998), except that the fusion peptide now inserts into the center of the cleaved HA trimer (Wilson et al. 1981).

HA-mediated membrane fusion is a $\mathrm{pH}$-dependent process that occurs in the endosome. 
N.C. Wu and I.A. Wilson

The acidic environment inside the endosome triggers the conformational change of HA (Fig. 2B), which in turn induces virus-host membrane fusion. The threshold $\mathrm{pH}$ of membrane fusion varies between strains and subtypes (ranging from $\sim 5.2$ to 6.0) (Scholtissek 1985; Puri et al. 1990; Korte et al. 2007; DuBois et al. 2011; Galloway et al. 2013), but is generally lower for HAs from human isolates than for HAs from avian isolates (Galloway et al. 2013). The conformational change of HA during fusion involves substantial structural rearrangements in the stem domain. Consistently, many residues in the stem domain are highly conserved, some of which are determinants of the threshold $\mathrm{pH}$ of membrane fusion (Daniels et al. 1985; Rachakonda et al. 2007; Thoennes et al. 2008; Xu and Wilson 2011; Mair et al. 2014; Byrd-Leotis et al. 2015).

\section{ANTIGENIC EVOLUTION OF HEMAGGLUTININ}

Identifying regions on $\mathrm{HA}$ that are targeted by humoral immune response has been a primary focus for influenza research. The antigenicity of $\mathrm{H} 1$ and $\mathrm{H} 3$ viruses has been studied most exten- sively among HA subtypes, because of their circulation in the human population. In early studies, five major antigenic sites were proposed for $\mathrm{H} 1 \mathrm{HAs}$ (Sa, Sb, Ca1, Ca2, and Cb) (Gerhard et al. 1981; Caton et al. 1982), as well as for H3 HA (sites A-E) (Wiley et al. 1981; Skehel et al. 1984; Wiley and Skehel 1987). All antigenic sites are located in the globular head domain for both $\mathrm{H} 1$ and $\mathrm{H} 3 \mathrm{HAs}$ (Fig. 3). In contrast to the HA globular head domain, the HA stem has a much lower efficiency in eliciting antibody responses and, hence, is less immunogenic (Jegaskanda et al. 2013; Altman et al. 2015; Angeletti et al. 2017; Tan et al. 2019).

To continue circulating in human populations, influenza viruses have to constantly evolve to escape herd immunity arising from natural infection and vaccination, via antigenic shift and antigenic drift. Antigenic shift involves the emergence of antigenically novel viral strains, whereas antigenic drift involves incremental changes in circulating viruses via mutation. Antigenic shift is rare as compared with antigenic drift, but can lead to devastating pandemic outbreaks. Antigenic shift often results from reassortment that involves acquisition of anti-
A

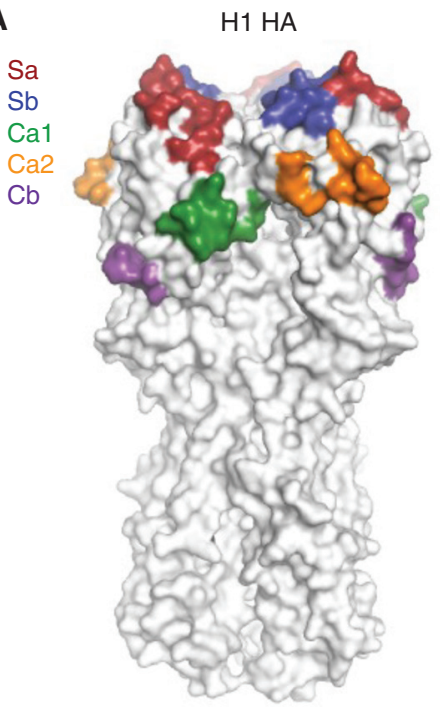

B

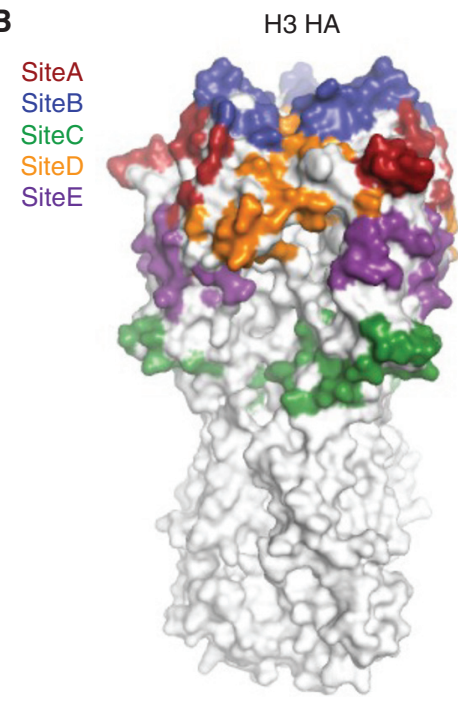

Figure 3. Major antigenic sites of hemagglutinin (HA). (A) The five major antigenic sites on H1 HA are illustrated. $(B)$ The five major antigenic sites on H3 HA are shown. 
genically novel HA or NA or both from avian viruses into human or other mammalian viruses (Lowen 2017). Antigenic shift is responsible for known influenza pandemics-the Spanish flu (H1N1) pandemic in 1918, the Asian flu (H2N2) pandemic in 1957, the Hong Kong flu (H3N2) pandemic in 1968, and the most recent swine flu (H1N1) pandemic in 2009. After each pandemic, the progeny influenza strains continue to evolve in the human population and escape herd immunity via antigenic drift. The evolutionary rates of $\mathrm{H} 1 \mathrm{~N} 1$ and $\mathrm{H} 3 \mathrm{~N} 2$ in humans are similar and are approximately twofold higher than that of influenza B virus (Furuse et al. 2016). The HA globular head domain evolves faster than the HA stem domain (Kirkpatrick et al. 2018), which is consistent with the notion that the HA globular head domain is immunodominant over the HA stem domain (Jegaskanda et al. 2013; Altman et al. 2015; Angeletti et al. 2017; Tan et al. 2019). Studies have also shown that major antigenic drift in human influenza evolution almost exclusively involves amino-acid substitutions in the major antigenic sites (Smith et al. 2004; Koel et al. 2013). Because the HA RBS partially overlaps with major antigenic sites ( $\mathrm{Sa}, \mathrm{Sb}$, and $\mathrm{Ca} 2$ of $\mathrm{H} 1 \mathrm{HA}$, and antigenic sites $\mathrm{A}, \mathrm{B}$, and $\mathrm{D}$ of $\mathrm{H} 3 \mathrm{HA}$ ) (Wu and Wilson 2017), antigenic drift may be associated with a change in receptor-binding avidity (Hensley et al. 2009; Li et al. 2013).

Accumulation of $\mathrm{N}$-glycosylation sites is a common immune evasion strategy that is utilized by diverse enveloped viruses (Davis et al. 1990; Simmonds et al. 1991; Cheng-Mayer et al. 1999; Fournillier et al. 2001; Zhang et al. 2004), including human influenza A viruses (Zhang et al. 2004; Blackburne et al. 2008; Igarashi et al. 2008; Cherry et al. 2009; Das et al. 2010; Sun et al. 2011; Lee et al. 2014; Tate et al. 2014; Wu and Wilson 2017; Altman et al. 2019). The accumulation of $\mathrm{N}$-glycosylation sites in the HA globular head domains of human influenza $\mathrm{A}$ viruses occurs at discrete 5- to-7-year intervals, until they reach a functional limit (Altman et al. 2019). After reaching this functional limit, which is $\sim 5$ for $\mathrm{H} 1 \mathrm{~N} 1$ and $\sim 7$ for H3N2, N-glycosylation sites are swapped (i.e., loss of one Nglycosylation site and gain of another at the same time through point mutations) at a longer interval (Altman et al. 2019). If an N-glycosylation site is added next to the RBS, it can negatively influence receptor binding (Tsuchiya et al. 2001, 2002; Das et al. 2011; Kim et al. 2013; Tate et al. 2014; Alymova et al. 2016). Subsequently, the RBS and immediate proximal region become relatively more exposed as $\mathrm{N}$-glycosylation sites accumulate and shield the rest of the HA globular head domain (Wu and Wilson 2017). Consistently, RBS-proximal antigenic site B has become immunodominant in recent human H3N2 HAs (Popova et al. 2012; Chambers et al. 2015), which are highly decorated with $\mathrm{N}$-glycans (Lee et al. 2014; Wu and Wilson 2017).

\section{ANTIBODIES AGAINST THE HEMAGGLUTININ STEM DOMAIN}

Most antibody responses focus on epitopes that are highly diverse among strains (Gerhard et al. 1981; Wiley et al. 1981; Caton et al. 1982) and are thus strain-specific (Wang et al. 1986; Wrammert et al. 2008). However, some HA antibodies can neutralize multiple strains within a subtype or even across subtypes by targeting conserved regions. These broadly neutralizing antibodies (bnAbs) target regions that are relatively conserved. The stem domain is one such region on HA (Wu and Wilson 2017). In 1993, a mouse antibody C179 was reported to have cross-subtype neutralization activity and was believed to bind to the stem domain (Okuno et al. 1993). In 2013, the structure of C179 in complex with HA confirmed that C179 indeed binds to the HA stem (Dreyfus et al. 2013). The 20-year delay in the structural characterization of C179 was due to the fact that the research on stem-binding bnAbs did not become active until 2008-2009. In 2008-2009, three sets of pan-group $1 \mathrm{HA}$ antibodies were isolated independently from human subjects in different continents (Kashyap et al. 2008; Throsby et al. 2008; Sui et al. 2009). In 2009, X-ray structural characterization revealed that antibodies CR6261 and F10 bound to a highly conserved epitope in the HA stem domain (Ekiert et al. 2009; Sui et al. 2009). These findings show that 
N.C. Wu and I.A. Wilson

influenza bnAbs can be elicited in humans and sparked considerable interest in studying human influenza bnAbs. In 2011, a pan-influenza A stem-binding bnAb FI6v3, which can target both group 1 and group 2 HAs, was reported (Corti et al. 2011). Nevertheless, despite different angles of approach to the HA surface and the use of both heavy and light chains for binding by FI6v3 versus only the heavy chain for CR6261, the epitopes of FI6v3 and CR6261 are highly overlapping. However, unlike CR6261, which utilized the $\mathrm{V}_{\mathrm{H}} 1-69$ germline gene, FI6v3 arose from the $\mathrm{V}_{\mathrm{H}} 3-30$ germline gene. In 2012, an antibody called CR9114, which can target both influenza A and B HAs, was reported (Dreyfus et al. 2012). Both CR9114 and CR6261 are encoded by $\mathrm{V}_{\mathrm{H}} 1-69$ and bind to a very similar epitope. During the late 2000s and subsequent years, many other stem-binding bnAbs from humans were discovered and characterized (Kashyap et al. 2008, 2010; Burioni et al. 2010; Clementi et al. 2011; Ekiert et al. 2011; Nakamura et al. 2013; Yasugi et al. 2013; Friesen et al. 2014; Henry Dunand et al. 2015, 2016; Wu et al. 2015, 2018b; Fu et al. 2016; Joyce et al. 2016;
Kallewaard et al. 2016; Andrews et al. 2017; Lang et al. 2017; Yamayoshi et al. 2017), including some that cross-react with both group 1 and 2 HAs (Nakamura et al. 2013; Henry Dunand et al. 2015, 2016; Wu et al. 2015; Fu et al. 2016; Joyce et al. 2016; Kallewaard et al. 2016; Andrews et al. 2017; Lang et al. 2017).

Structural characterization of stem-binding bnAbs antibodies illustrated that most stembinding bnAbs have an epitope that highly overlaps with that of CR6261 (Fig. 4A) (Wu and Wilson 2018), although group 2-specific stembinding bnAbs bind slightly lower down the stem domain (Fig. 4B) (Ekiert et al. 2011; Friesen et al. 2014). Five pockets in the stem domain are often targeted by stem-binding bnAbs, mainly using hydrophobic and aromatic residues (Fig. 4C) (Kadam et al. 2017). Identification of these common binding features facilitated structure-based design of stem-binding proteins (Fleishman et al. 2011; Whitehead et al. 2012; Chevalier et al. 2017), peptides (Kadam et al. 2017), and small molecules (van Dongen et al. 2019) with neutralizing activity akin to the bnAbs.
A

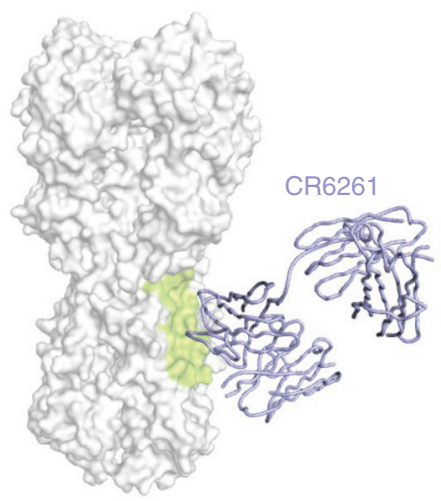

B

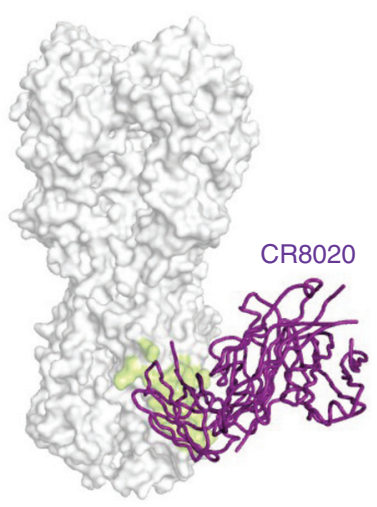

C

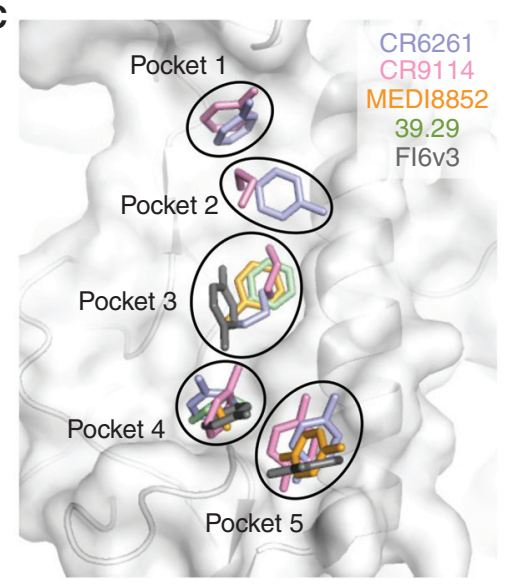

Figure 4. Hemagglutinin (HA) stem-binding antibodies. (A) Binding of group 1-specific broadly neutralizing antibody (bnAb) CR6261 to HA (Ekiert et al. 2009). (B) Binding of group 2-specific bnAb CR8020 to HA (Ekiert et al. 2011). $(A, B)$ The HA surface is colored in white and bnAb epitope colored in lime. $(C)$ Pockets that are commonly targeted by HA stem-binding antibodies are shown. Side chains of key binding residues in the paratopes (i.e., the parts of an antibody that bind to the epitope, usually the complementarity determining regions [CDRs], but can also include some framework residues) of CR6261 (Ekiert et al. 2009), CR9114 (Dreyfus et al. 2012), MEDI8852 (Kallewaard et al. 2016), 39.29 (Nakamura et al. 2013), and FI6v3 (Corti et al. 2011) are shown in stick representation. The HA surface and underlying backbone structure are colored in white. 
Although the stem-binding bnAb epitopes are highly conserved, variations can be observed in some of the epitope or epitope-proximal residues and can limit the breadth of stem-binding bnAbs (Zost et al. 2019). A well-known example is the N-glycosylation site at HA1 Asn38, which is adjacent to the conserved stem epitope (Ekiert et al. 2009; Sui et al. 2009). The N-glycosylation site at HA1 Asn38 is not present among group $1 \mathrm{HAs}$, but is highly conserved among group 2 HAs. The N-glycan at HA1 Asn38 can block binding of stem-binding bnAbs to group 2 HAs. Binding to group $2 \mathrm{HAs}$ often involves a reorientation of the group 2-specific glycan at HA1 Asn38 and other residues, including HA2 Trp 21 (Corti et al. 2011; Dreyfus et al. 2012). Structural comparison of $\mathrm{V}_{\mathrm{H}} 1-69$-encoded stem-binding bnAbs suggests that the precise approach angle of stem-binding bnAbs is a determinant of whether the N-glycan at HA1 Asn38 can be accommodated (Lang et al. 2017).

\section{ANTIBODIES AGAINST THE HEMAGGLUTININ RECEPTOR-BINDING SITE}

Another conserved region on HA is the RBS, despite being more variable than the stem domain (Wu and Wilson 2017). A number of RBS-targeting bnAbs have been identified and characterized (Fleury et al. 1998; Barbey-Martin et al. 2002; Yoshida et al. 2009; Krause et al. 2011, 2012; Ohshima et al. 2011; Whittle et al. 2011; Ekiert et al. 2012; Lee et al. 2012, 2014; Tsibane et al. 2012; Hong et al. 2013; Schmidt et al. 2013; Xu et al. 2013; Lee and Wilson 2015; McCarthy et al. 2018). By targeting the receptorbinding sites, these bnAbs prevent HA from binding to the receptor. Unlike the stem domain, which is close to the viral membrane, the RBS is highly exposed. Therefore, RBS-targeted bnAbs can adopt a much wider range of approach angles when engaging the $\mathrm{HA}$ as compared with stem-binding bnAbs (Wu and Wilson 2017). By comparing the structures of RBS-targeting bnAbs, several common features were revealed. RBS-targeting bnAbs often insert a single complementarity determining region (CDR) loop, mostly CDR H3 but occasionally
$\mathrm{H} 2$, into the RBS (Fig. 5A,B) (Lee and Wilson 2015). The tips of these CDR loops mimic the binding mode of sialic acid (Lee and Wilson 2015). The most common strategy is to mimic the acetamide group of sialic acid using a hydrophobic, often aromatic, amino acid, such as Trp (Ekiert et al. 2012), Tyr (Fleury et al. 1998; Xu et al. 2013), Phe (Xu et al. 2013), Met (Lee et al. 2012), Leu (Lee et al. 2014), Val (Whittle et al. 2011; Schmidt et al. 2015), and Pro (Fig. 5C) (Hong et al. 2013; Schmidt et al. 2015). Mimicking the sialic acid carboxylate group is another strategy that is utilized by some RBS-targeting bnAbs to enable formation of an extensive hydrogen bond network. A number of RBS-targeting bnAbs are able to completely mimic the carboxylate group using an Asp at the tip of CDR H3 (Fig. 5D) (Whittle et al. 2011; Hong et al. 2013; Schmidt et al. 2013, 2015; Lee et al. 2014), whereas some other RBS-targeting bnAbs partially mimic the carboxylate group using a backbone carbonyl group (Ekiert et al. 2012; Lee et al. 2012; McCarthy et al. 2018). Structural characterization of RBS-targeting bnAbs has also inspired the development of anti-influenza protein binders against the RBS (Strauch et al. 2017). In addition, by harnessing the knowledge of RBS-targeting and stem-binding bnAbs, a multidomain llama antibody has been developed, which can broadly cross-neutralize influenza A and B viruses (Laursen et al. 2018).

Because small variations can be found within the HA RBS as well as high variability in the RBSproximal regions ( $\mathrm{Wu}$ and Wilson 2017), it is difficult for RBS-targeted bnAbs to completely avoid contacting variable regions, despite their small binding footprints using a single CDR. As a result, the reactivity of RBS-targeted bnAbs is generally not as broad as stem-binding bnAbs. Many RBS-targeted bnAbs are subtype-specific (Whittle et al. 2011; Hong et al. 2013; Schmidt et al. 2013, 2015), and some can cross-react with a limited number of subtypes (Yoshida et al. 2009; Ohshima et al. 2011; Ekiert et al. 2012; Krause et al. 2012; Lee et al. 2012, 2014; Xu et al. 2013; McCarthy et al. 2018). It has been proposed that the bivalence of immunoglobulin G (IgG) confers RBS-targeted bnAbs with an avidity effect, by binding to two adjacent trimers simulta- 
N.C. Wu and I.A. Wilson

A

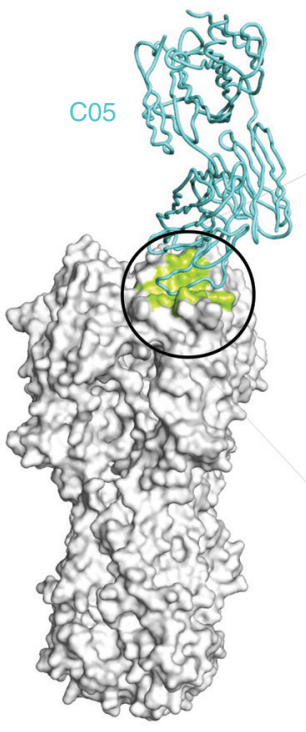

C

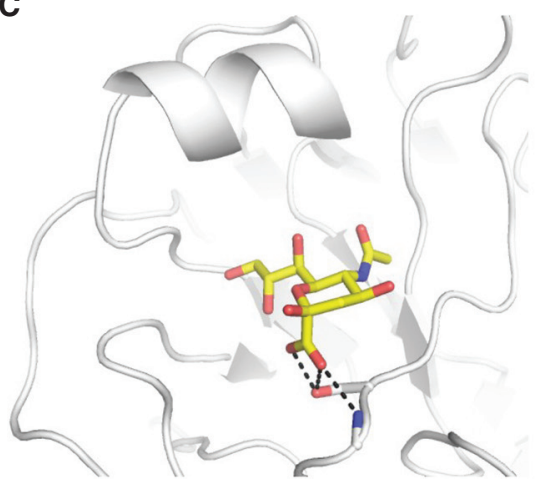

B

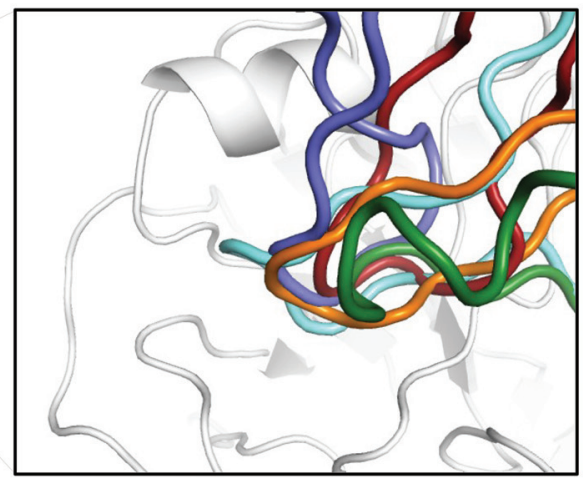

D

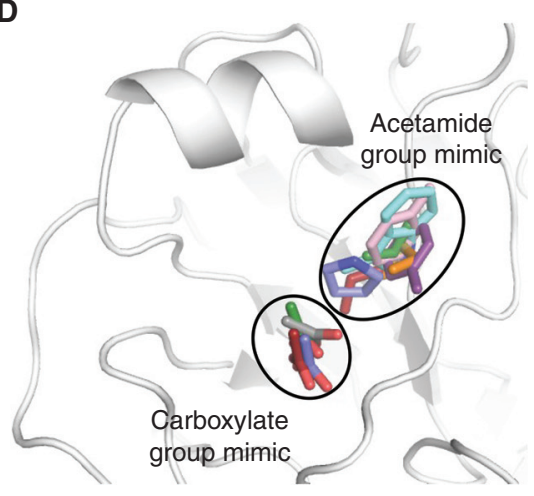

Figure 5. Hemagglutinin (HA) receptor-binding site (RBS)-targeting antibodies. (A) Structure of a prototypic RBS-targeting antibody $\mathrm{C} 05$ in complex with HA (Ekiert et al. 2012). HA is colored in white and the C05 epitope is colored in lime. (B) bnAbs C05 (cyan), F045-092 (green), 5J8 (slate blue), and CH65 (red) target the HA RBS using their complementarity determining region (CDR) H3 (Whittle et al. 2011; Ekiert et al. 2012; Hong et al. 2013; Lee et al. 2014). S139/1 (orange) targets the HA RBS using its CDR H2 (Lee et al. 2012). (C) Sialic acid in complex with HA. Hydrogen bonds between the carboxylate group of sialic acid and HA are shown in black dashed lines. $(D)$ The carboxylate and acetamide groups of sialic acid are mimicked by RBS-targeting antibodies, including C05 (cyan) (Ekiert et al. 2012), S139/1 (orange) (Lee et al. 2012), F045-092 (green) (Lee et al. 2014), 2G1 (purple) (Xu et al. 2013), 8M2 (pink) (Xu et al. 2013), 5J8 (slate blue) (Hong et al. 2013), HC63 (gray) (Barbey-Martin et al. 2002), and CH65 (red) (Whittle et al. 2011). The side chains that act as mimics of sialic acid receptor moieties are shown in stick representation.

neously (Ekiert et al. 2012; Lee et al. 2012). As a result, the potency of RBS-targeting bnAbs is usually higher than stem-binding bnAbs. Cross-linking HA trimers on the viral surface by RBS-targeting bnAbs may also prevent HA conformational changes that normally occur during membrane fusion (Barbey-Martin et al. 2002).

\section{OTHER BROADLY REACTIVE ANTIBODIES AGAINST HEMAGGLUTININ}

Other regions on HA besides the RBS and stem domain are also targeted by bnAbs. Because most regions on HA besides the RBS and stem domain are highly diverse across HA subtypes, 
bnAbs that do not target the RBS or the stem domain are usually subtype-specific. One example is the vestigial esterase subdomain on HAl, which is conserved among strains within a certain subtype but not across subtypes (Fig. 6A). Several protective antibodies that target the vestigial esterase subdomain have been characterized (Li et al. 2009; Dreyfus et al. 2012; Zhu et al. 2013a; Zuo et al. 2015; Chai et al. 2017; Bangaru et al. 2018), including H5M9 (Li et al. 2009; Zhu et al. 2013a), CR8071 (Dreyfus et al. 2012), 46B8 (Chai et al. 2017), 100F4 (Zuo et al. 2015), F005126 (Iba et al. 2014), and H3v-47 (Bangaru et al. 2018). Both H5M9, which is a mouse antibody, and $100 \mathrm{~F} 4$, which is a human antibody, target multiple clades of H5N1 viruses. CR8071 and 46B8 are human antibodies that target influenza $B$ viruses, whereas $\mathrm{F} 005-126$ and $\mathrm{H} 3 \mathrm{v}-47$ are human antibodies that target diverse strains of H3N2 viruses. Although these bnAbs all target the vestigial esterase subdomain, their mechanisms of action are different. H5M9, 46B8, and F005-126 prevent the $\mathrm{pH}$-dependent conformational changes of the HA, which is required for virus-host membrane fusion (Li et al. 2009; Zhu et al. 2013a), whereas CR8071 and H3v-47 primarily function via blocking the viral budding and progeny release process (Brandenburg et al. 2013; Bangaru et al. 2018).

Besides the vestigial esterase subdomain, some other regions on $\mathrm{HA}$ are also bnAb epitopes. For example, Ab6649 is a human H1-specific bnAb that targets an epitope above the vestigial esterase subdomain on HA1 and is highly conserved among H1N1 strains (Fig. 6B) (Raymond et al. 2018). Antibodies H7.137, H7.167, and H7.169 are H7-specific bnAbs that bind to a similar epitope that is highly conserved within the H7 subtype (Thornburg et al. 2016). An H1-specific bnAb FISW84 binds to an epitope that is near the ectodomain membrane anchor junction and is conserved among $\mathrm{H1}$ HAs (Benton et al. 2018). Antibodies D1 H13/H3-3, D1 H1-17/H3-14, and D2 H1-1/H3-1, which are nonneutralizing but offer in vivo protection, target a conserved epitope that is slightly below the RBS and can cross-react with both $\mathrm{H} 1$ and $\mathrm{H} 3$ subtypes (Lee et al. 2016).

Recent studies have revealed that antibodies can target conserved epitopes in HA1 that involve the trimer interface, which is not solvent-accessible in the conventional HA trimer configuration (Bajic et al. 2019; Bangaru et al. 2019; Turner et al. 2019; Watanabe et al. 2019).
A

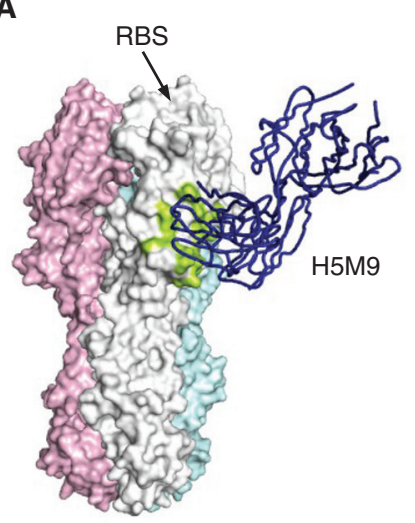

B

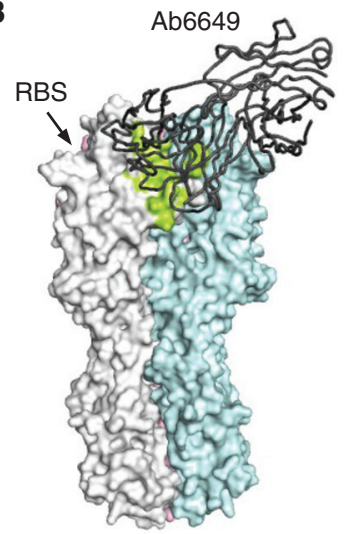

C

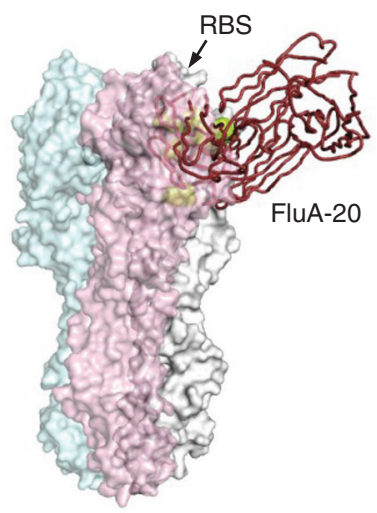

Figure 6. Other neutralizing epitopes on hemagglutinin (HA). (A) Binding of 5HM9 to HA in the vestigial esterase region (Zhu et al. 2013a). (B) Binding of Ab6649 to HA in the "lateral patch" on the globular head domain, which is next to the receptor-binding site (RBS) and above the vestigial esterase subdomain (Raymond et al. 2018). (C) Binding of FluA-20 to the HA trimer interface (Bangaru et al. 2019). The epitope of FluA-20 is located in a conserved region in the HA protomer-protomer interface. Therefore, binding of FluA-20 to HA requires dissociation or breathing of the HA trimer. $(A-C)$ Three protomers of the HA trimer are colored in white, pink, and cyan, respectively. The epitope is colored in lime. The location of the RBS is indicated. 
H7.5 is a human H7-specific bnAb that targets an epitope that involves adjacent protomers in the HA trimer (Thornburg et al. 2016; Turner et al. 2019). Part of the H7.5 epitope involves the trimer interface, suggesting that HA1 globular head is structurally dynamic in its prefusion state (Turner et al. 2019). Single-molecule Förster resonance energy transfer (FRET) also reveals that HA undergoes reversible conformational changes (Garcia et al. 2015). The epitopes of other HA interface-targeting antibodies, such as FluA-20 (Bangaru et al. 2019), S5V2-29 (Watanabe et al. 2019), H2214 (Watanabe et al. 2019), and 8H10 (Bajic et al. 2019), are mainly composed of residues in the trimer interface (Fig. 6C). FluA-20 has the largest breadth among these antibodies, with the ability to bind to 14 out of 15 tested HA subtypes. Electron microscopy (EM) analysis indicated that these HA interface-targeting antibodies can induce dissociation of the HA trimer (Bangaru et al. 2019; Turner et al. 2019). Nonetheless, the mechanisms of action of these interface-targeting antibodies are different. Although H7.5 has neutralizing activity (Thornburg et al. 2016), FluA-20, S5V2-29, H2214, and 8H10 have no direct neutralizing activity (Bajic et al. 2019; Bangaru et al. 2019; Watanabe et al. 2019). These interface-targeting antibodies appear to offer in vivo protection through antibody-dependent cellular cytotoxicity (ADCC) (Bangaru et al. 2019; Watanabe et al. 2019).

\section{VACCINES AGAINST HEMAGGLUTININ}

Structural characterization of bnAbs has been a major driver of universal influenza vaccine development. Antibodies elicited by seasonal influenza vaccine are typically strain-specific. As a result, the components of seasonal influenza vaccine have to be annually reviewed and updated, if necessary, to account for the antigenic drift of the circulating strains. However, antigenic mismatch between the vaccine strains and the circulating strains occur occasionally (Tricco et al. 2013). In addition, most seasonal influenza vaccines are produced in embryonated chicken eggs, which may result in HA egg-adaptive mutations that change the antigenicity of the vac- cine strains (Robertson et al. 1987; Kodihalli et al. 1995; Chen et al. 2010; Popova et al. 2012; Parker et al. 2016; Raymond et al. 2016; Wu et al. 2017; Zost et al. 2017). Egg-adaptation mutations allow HAs from human influenza viruses, which has a receptor specificity toward $\alpha 2,6$-linked sialic acid, to increase affinity to $\alpha 2,3$-linked sialic acid (Wu et al. 2017, 2019), which is abundant on the chorioallantoic membrane (Ito et al. 1997; Sriwilaijaroen et al. 2009). As a result, the effectiveness of seasonal influenza vaccine is far from satisfying (Belongia et al. 2016).

A major direction of influenza vaccine research is to develop immunogens that can elicit protective antibodies against multiple strains or even subtypes, such that annual updates of the influenza vaccine are not needed. HA stembinding bnAbs have provided significant insight into structural-based design of such immunogens (Wu and Wilson 2018). Several stem immunogens that can elicit heterosubtypic antibodies have been described (Steel et al. 2010; Bommakanti et al. 2012; Mallajosyula et al. 2014, 2015; Impagliazzo et al. 2015; Wohlbold et al. 2015; Yassine et al. 2015; Valkenburg et al. 2016; Corbett et al. 2019). Some of these stem immunogens are referred to as "headless HA" (Steel et al. 2010; Valkenburg et al. 2016; Corbett et al. 2019), because they are basically HA without the globular head domain. The general framework for stem immunogen design is to link the aminoand carboxy-terminal regions of the HAl chain with the entire HA2 chain. Displaying these stem immunogens on nanoparticles can enhance their immunogenicity (Yassine et al. 2015; Corbett et al. 2019). Thus, these stem immunogens are promising candidates for a universal influenza vaccine.

\section{CONCLUDING REMARKS}

Although the first structure of HA was reported almost 40 years ago, knowledge of HA recognition by antibodies had remained limited for many years. Because the major antigenic sites on HA are highly variable, it has been long believed that human antibodies with heterosubtypic activity against HA did not exist. None- 
theless, over the past decade, many human bnAbs to HA have been discovered and characterized. These bnAbs can neutralize multiple strains within a given subtype or across multiple subtypes. Structural characterization has shown that the epitopes of these bnAbs are distinct from the classic antigenic sites. Most HA bnAbs target the RBS or the stem domain, which are both evolutionarily conserved owing to functional constraints. These bnAbs have provided important insight into universal influenza vaccine design and also for the design of multidomain antibody, small protein, peptide, and small molecule therapeutic candidates.

\section{ACKNOWLEDGMENTS}

This work was supported by the Bill and Melinda Gates Foundation Post-Doctoral Fellowship in Global Health (N.C.W.) and the Bill and Melinda Gates Foundation OPP1170236 (I.A.W.).

This article has been made freely available online courtesy of TAUNS Laboratories.

\section{REFERENCES}

Altman MO, Bennink JR, Yewdell JW, Herrin BR. 2015. Lamprey VLRB response to influenza virus supports universal rules of immunogenicity and antigenicity. eLlife 4: e07467. doi:10.7554/eLife.07467

Altman MO, Angel M, Košik I, Trovão NS, Zost SJ, Gibbs JS, Casalino L, Amaro RE, Hensley SE, Nelson MI, et al. 2019. Human influenza A virus hemagglutinin glycan evolution follows a temporal pattern to a glycan limit. mBio 10: e00204-e00219. doi:10.1128/mBio.00204-19

Alymova IV, York IA, Air GM, Cipollo JF, Gulati S, Baranovich T, Kumar A, Zeng H, Gansebom S, McCullers JA. 2016. Glycosylation changes in the globular head of H3N2 influenza hemagglutinin modulate receptor binding without affecting virus virulence. Sci Rep 6: 36216. doi:10.1038/srep36216

Andrews SF, Joyce MG, Chambers MJ, Gillespie RA, Kanekiyo M, Leung K, Yang ES, Tsybovsky Y, Wheatley AK, Crank MC, et al. 2017. Preferential induction of crossgroup influenza A hemagglutinin stem-specific memory B cells after H7N9 immunization in humans. Sci Immunol 2: eaan2676. doi:10.1126/sciimmunol.aan2676

Angeletti D, Gibbs JS, Angel M, Kosik I, Hickman HD, Frank GM, Das SR, Wheatley AK, Prabhakaran M, Leggat DJ, et al. 2017. Defining B cell immunodominance to viruses. Nat Immunol 18: 456-463. doi:10.1038/ni.3680

Bajic G, Maron MJ, Adachi Y, Onodera T, McCarthy KR, McGee CE, Sempowski GD, Takahashi Y, Kelsoe G, Kur- aoka M, et al. 2019. Influenza antigen engineering focuses immune responses to a subdominant but broadly protective viral epitope. Cell Host Microbe 25: 827-835.e6. doi:10.1016/j.chom.2019.04.003

Bangaru S, Zhang H, Gilchuk IM, Voss TG, Irving RP, Gilchuk P, Matta P, Zhu X, Lang S, Nieusma T, et al. 2018. A multifunctional human monoclonal neutralizing antibody that targets a unique conserved epitope on influenza HA. Nat Commun 9: 2669. doi:10.1038/s41467-01804704-9

Bangaru S, Lang S, Schotsaert M, Vanderven HA, Zhu X, Kose N, Bombardi R, Finn JA, Kent SJ, Gilchuk P, et al. 2019. A site of vulnerability on the influenza virus hemagglutinin head domain trimer interface. Cell 177: 11361152.e18. doi:10.1016/j.cell.2019.04.011

Barbey-Martin C, Gigant B, Bizebard T, Calder LJ, Wharton SA, Skehel JJ, Knossow M. 2002. An antibody that prevents the hemagglutinin low $\mathrm{pH}$ fusogenic transition. $\mathrm{Vi}$ rology 294: 70-74. doi:10.1006/viro.2001.1320

Belongia EA, Simpson MD, King JP, Sundaram ME, Kelley NS, Osterholm MT, McLean HQ. 2016. Variable influenza vaccine effectiveness by subtype: a systematic review and meta-analysis of test-negative design studies. Lancet Infect Dis 16: 942-951. doi:10.1016/S1473-3099(16) 00129-8

Benton DJ, Nans A, Calder LJ, Turner J, Neu U, Lin YP, Ketelaars E, Kallewaard NL, Corti D, Lanzavecchia A, et al. 2018. Influenza hemagglutinin membrane anchor. Proc Natl Acad Sci 115: 10112-10117. doi:10 $.1073 /$ pnas. 1810927115

Bizebard T, Gigant B, Rigolet P, Rasmussen B, Diat O, Bösecke P, Wharton SA, Skehel JJ, Knossow M. 1995. Structure of influenza virus haemagglutinin complexed with a neutralizing antibody. Nature 376: 92-94. doi:10.1038/ 376092a0

Blackburne BP, Hay AJ, Goldstein RA. 2008. Changing selective pressure during antigenic changes in human influenza H3. PLoS Pathog 4: e1000058. doi:10.1371/jour nal.ppat. 1000058

Bommakanti G, Lu X, Citron MP, Najar TA, Heidecker GJ, ter Meulen J, Varadarajan R, Liang X. 2012. Design of Escherichia coli-expressed stalk domain immunogens of H1N1 hemagglutinin that protect mice from lethal challenge. J Virol 86: 13434-13444. doi:10.1128/JVI.01429-12

Böttcher E, Matrosovich T, Beyerle M, Klenk HD, Garten W, Matrosovich M. 2006. Proteolytic activation of influenza viruses by serine proteases TMPRSS2 and HAT from human airway epithelium. J Virol 80: 9896-9898. doi:10 $.1128 /$ JVI.01118-06

Böttcher-Friebertshauser E, Klenk HD, Garten W. 2013. Activation of influenza viruses by proteases from host cells and bacteria in the human airway epithelium. Pathog Dis 69: 87-100. doi:10.1111/2049-632X.12053

Brandenburg B, Koudstaal W, Goudsmit J, Klaren V, Tang C, Bujny MV, Korse HJ, Kwaks T, Otterstrom JJ, Juraszek J, et al. 2013. Mechanisms of hemagglutinin targeted influenza virus neutralization. PLoS ONE 8: e80034. doi:10 .1371/journal.pone.0080034

Bullough PA, Hughson FM, Treharne AC, Ruigrok RW, Skehel JJ, Wiley DC. 1994. Crystals of a fragment of influenza haemagglutinin in the low $\mathrm{pH}$ induced confor- 
N.C. Wu and I.A. Wilson

mation. J Mol Biol 236: 1262-1265. doi:10.1016/00222836(94)90027-2

Burioni R, Canducci F, Mancini N, Clementi N, Sassi M, De Marco D, Diotti RA, Saita D, Sampaolo M, Sautto G, et al. 2010. Monoclonal antibodies isolated from human B cells neutralize a broad range of $\mathrm{H} 1$ subtype influenza A viruses including swine-origin Influenza virus (S-OIV). Virology 399: 144-152. doi:10.1016/j.virol.2009.12.014

Burnet FM, Stone JD. 1947. The receptor-destroying enzyme of V. cholerae. Aust J Exp Biol Med Sci 25: 227-233. doi:10 1038/icb.1947.33

Byrd-Leotis L, Galloway SE, Agbogu E, Steinhauer DA. 2015. Influenza hemagglutinin (HA) stem region mutations that stabilize or destabilize the structure of multiple HA subtypes. J Virol 89: 4504-4516. doi:10.1128/JVI.00057-5

Casadevall A, Imperiale MJ. 2014. Risks and benefits of gainof-function experiments with pathogens of pandemic potential, such as influenza virus: a call for a science-based discussion. mBio 5: e01730-e01714. doi: 10.1128/mBio .01730-14

Caton AJ, Brownlee GG, Yewdell JW, Gerhard W. 1982. The antigenic structure of the influenza virus $\mathrm{A} / \mathrm{PR} / 8 / 34 \mathrm{hem}-$ agglutinin (H1 subtype). Cell 31: 417-427. doi:10.1016/ 0092-8674(82)90135-0

Chai N, Swem LR, Park S, Nakamura G, Chiang N, Estevez A, Fong R, Kamen L, Kho E, Reichelt M, et al. 2017. A broadly protective therapeutic antibody against influenza $\mathrm{B}$ virus with two mechanisms of action. Nat Commun 8: 14234. doi:10.1038/ncomms14234

Chambers BS, Parkhouse K, Ross TM, Alby K, Hensley SE. 2015. Identification of hemagglutinin residues responsible for H3N2 antigenic drift during the 2014-2015 influenza season. Cell Rep 12: 1-6. doi:10.1016/j.celrep.2015 .06 .005

Chen J, Lee KH, Steinhauer DA, Stevens DJ, Skehel JJ, Wiley DC. 1998. Structure of the hemagglutinin precursor cleavage site, a determinant of influenza pathogenicity and the origin of the labile conformation. Cell 95: 409417. doi:10.1016/S0092-8674(00)81771-7

Chen J, Skehel JJ, Wiley DC. 1999. N- and C-terminal residues combine in the fusion-pH influenza hemagglutinin $\mathrm{HA}_{2}$ subunit to form an $\mathrm{N}$ cap that terminates the triplestranded coiled coil. Proc Natl Acad Sci 96: 8967-8972. doi:10.1073/pnas.96.16.8967

Chen Z, Zhou H, Jin H. 2010. The impact of key amino acid substitutions in the hemagglutinin of influenza A (H3N2) viruses on vaccine production and antibody response. Vaccine 28: 4079-4085. doi:10.1016/j.vaccine.2010.03 .078

Cheng-Mayer C, Brown A, Harouse J, Luciw PA, Mayer AJ 1999. Selection for neutralization resistance of the simian/ human immunodeficiency virus SHIVSF33A variant in vivo by virtue of sequence changes in the extracellular envelope glycoprotein that modify N-linked glycosylation. J Virol 73: 5294-5300.

Cherry JL, Lipman DJ, Nikolskaya A, Wolf YI. 2009. Evolutionary dynamics of $\mathrm{N}$-glycosylation sites of influenza virus hemagglutinin. PLoS Curr 1: RRN1001. doi:10 $.1371 /$ currents.RRN1001

Chevalier A, Silva DA, Rocklin GJ, Hicks DR, Vergara R, Murapa P, Bernard SM, Zhang L, Lam KH, Yao G, et al. 2017. Massively parallel de novo protein design for tar- geted therapeutics. Nature 550: 74-79. doi:10.1038/na ture23912

Clementi N, De Marco D, Mancini N, Solforosi L, Moreno GJ, Gubareva LV, Mishin V, Di Pietro A, Vicenzi E, Siccardi AG, et al. 2011. A human monoclonal antibody with neutralizing activity against highly divergent influenza subtypes. PLOS ONE 6: e28001. doi:10.1371/journal pone.0028001

Connor RJ, Kawaoka Y, Webster RG, Paulson JC. 1994. Receptor specificity in human, avian, and equine $\mathrm{H} 2$ and $\mathrm{H} 3$ influenza virus isolates. Virology 205: 17-23. doi:10.1006/ viro.1994.1615

Corbett KS, Moin SM, Yassine HM, Cagigi A, Kanekiyo M, Boyoglu-Barnum S, Myers SI, Tsybovsky Y, Wheatley AK, Schramm CA, et al. 2019. Design of nanoparticulate group 2 influenza virus hemagglutinin stem antigens that activate unmutated ancestor B cell receptors of broadly neutralizing antibody lineages. mBio 10: $\mathrm{e} 02810-\mathrm{e} 02818$. doi:10.1128/mBio.02810-18

Corti D, Voss J, Gamblin SJ, Codoni G, Macagno A, Jarrossay D, Vachieri SG, Pinna D, Minola A, Vanzetta F, et al. 2011. A neutralizing antibody selected from plasma cells that binds to group 1 and group 2 influenza $\mathrm{A}$ hemagglutinins. Science 333: 850-856. doi:10.1126/science .1205669

Daniels RS, Downie JC, Hay AJ, Knossow M, Skehel JJ, Wang ML, Wiley DC. 1985. Fusion mutants of the influenza virus hemagglutinin glycoprotein. Cell 40: 431-439. doi:10.1016/0092-8674(85)90157-6

Das SR, Puigbò P, Hensley SE, Hurt DE, Bennink JR, Yewdell JW. 2010. Glycosylation focuses sequence variation in the influenza A virus $\mathrm{H} 1$ hemagglutinin globular domain. PLoS Pathog 6: e1001211. doi:10.1371/journal.ppat .1001211

Das SR, Hensley SE, David A, Schmidt L, Gibbs JS, Puigbo P, Ince WL, Bennink JR, Yewdell JW. 2011. Fitness costs limit influenza A virus hemagglutinin glycosylation as an immune evasion strategy. Proc Natl Acad Sci 108: E1417-E1422. doi:10.1073/pnas.1108754108

Davis D, Stephens DM, Willers C, Lachmann PJ. 1990. Glycosylation governs the binding of antipeptide antibodies to regions of hypervariable amino acid sequence within recombinant gp120 of human immunodeficiency virus type 1. J Gen Virol 71: 2889-2898. doi:10.1099/00221317-71-12-2889

de Vries RP, Zhu X, McBride R, Rigter A, Hanson A, Zhong G, Hatta M, Xu R, Yu W, Kawaoka Y, et al. 2014. Hemagglutinin receptor specificity and structural analyses of respiratory droplet-transmissible $\mathrm{H} 5 \mathrm{~N} 1$ viruses. J Virol 88: 768-773. doi:10.1128/JVI.02690-13

de Vries RP, Peng W, Grant OC, Thompson AJ, Zhu X, Bouwman KM, de la Pena ATT, van Breemen MJ, Ambepitiya Wickramasinghe IN, de Haan CAM, et al. 2017a. Three mutations switch H7N9 influenza to human-type receptor specificity. PLoS Pathog 13: e1006390. doi:10 .1371/journal.ppat.1006390

de Vries RP, Tzarum N, Peng W, Thompson AJ, Ambepitiya Wickramasinghe IN, de la Pena ATT, van Breemen MJ, Bouwman KM, Zhu X, McBride R, et al. 2017b. A single mutation in Taiwanese H6N1 influenza hemagglutinin switches binding to human-type receptors. $E M B O \mathrm{Mol}$ Med 9: 1314-1325. doi:10.15252/emmm.201707726 
Dreyfus C, Laursen NS, Kwaks T, Zuijdgeest D, Khayat R, Ekiert DC, Lee JH, Metlagel Z, Bujny MV, Jongeneelen M, et al. 2012. Highly conserved protective epitopes on influenza B viruses. Science 337: 1343-1348. doi:10.1126/ science. 1222908

Dreyfus C, Ekiert DC, Wilson IA. 2013. Structure of a classical broadly neutralizing stem antibody in complex with a pandemic $\mathrm{H} 2$ influenza virus hemagglutinin. J Virol 87: 7149-7154. doi:10.1128/JVI.02975-12

DuBois RM, Zaraket H, Reddivari M, Heath RJ, White SW, Russell CJ. 2011. Acid stability of the hemagglutinin protein regulates $\mathrm{H} 5 \mathrm{~N} 1$ influenza virus pathogenicity. PLoS Pathog 7: e1002398. doi:10.1371/journal.ppat.1002398

Ekiert DC, Bhabha G, Elsliger MA, Friesen RH, Jongeneelen M, Throsby M, Goudsmit J, Wilson IA. 2009. Antibody recognition of a highly conserved influenza virus epitope. Science 324: 246-251. doi:10.1126/science.1171491

Ekiert DC, Friesen RH, Bhabha G, Kwaks T, Jongeneelen M, Yu W, Ophorst C, Cox F, Korse HJ, Brandenburg B, et al. 2011. A highly conserved neutralizing epitope on group 2 influenza A viruses. Science 333: 843-850. doi:10.1126/ science.1204839

Ekiert DC, Kashyap AK, Steel J, Rubrum A, Bhabha G, Khayat R, Lee JH, Dillon MA, O'Neil RE, Faynboym AM, et al. 2012. Cross-neutralization of influenza A viruses mediated by a single antibody loop. Nature 489: 526-532. doi:10.1038/nature11414

Fleishman SJ, Whitehead TA, Ekiert DC, Dreyfus C, Corn JE, Strauch EM, Wilson IA, Baker D. 2011. Computational design of proteins targeting the conserved stem region of influenza hemagglutinin. Science 332: 816-821. doi:10 $.1126 /$ science. 1202617

Fleury D, Wharton SA, Skehel JJ, Knossow M, Bizebard T. 1998. Antigen distortion allows influenza virus to escape neutralization. Nat Struct Biol 5: 119-123. doi:10.1038/ nsb0298-119

Fournillier A, Wychowski C, Boucreux D, Baumert TF, Meunier JC, Jacobs D, Muguet S, Depla E, Inchauspe G. 2001. Induction of hepatitis $C$ virus E1 envelope proteinspecific immune response can be enhanced by mutation of N-glycosylation sites. J Virol 75: 12088-12097. doi:10 $.1128 / J V I .75 .24 .12088-12097.2001$

Friesen RH, Lee PS, Stoop EJ, Hoffman RM, Ekiert DC, Bhabha G, Yu W, Juraszek J, Koudstaal W, Jongeneelen $\mathrm{M}$, et al. 2014. A common solution to group 2 influenza virus neutralization. Proc Natl Acad Sci 111: 445-450. doi:10.1073/pnas.1319058110

Fu Y, Zhang Z, Sheehan J, Avnir Y, Ridenour C, Sachnik T, Sun J, Hossain MJ, Chen LM, Zhu Q, et al. 2016. A broadly neutralizing anti-influenza antibody reveals ongoing capacity of haemagglutinin-specific memory B cells to evolve. Nat Commun 7: 12780. doi:10.1038/ ncomms 12780

Furuse Y, Matsuzaki Y, Nishimura H, Oshitani H. 2016. Analyses of evolutionary characteristics of the hemagglutinin-esterase gene of influenza $\mathrm{C}$ virus during a period of 68 years reveals evolutionary patterns different from influenza A and B viruses. Viruses 8: 321. doi:10.3390/ v8120321

Galloway SE, Reed ML, Russell CJ, Steinhauer DA. 2013. Influenza HA subtypes demonstrate divergent phenotypes for cleavage activation and $\mathrm{pH}$ of fusion: implica- tions for host range and adaptation. PLoS Pathog 9: e1003151. doi:10.1371/journal.ppat.1003151

Garcia NK, Guttman M, Ebner JL, Lee KK. 2015. Dynamic changes during acid-induced activation of influenza hemagglutinin. Structure 23: 665-676. doi:10.1016/j.str.2015 .02 .006

Garman EF. 2014. Developments in X-ray crystallographic structure determination of biological macromolecules. Science 343: 1102-1108. doi:10.1126/science. 1247829

Gerhard W, Yewdell J, Frankel ME, Webster R. 1981. Antigenic structure of influenza virus haemagglutinin defined by hybridoma antibodies. Nature 290: 713-717. doi:10 1038/290713a0

Glaser L, Stevens J, Zamarin D, Wilson IA, García-Sastre A, Tumpey TM, Basler CF, Taubenberger JK, Palese P. 2005. A single amino acid substitution in 1918 influenza virus hemagglutinin changes receptor binding specificity. $J \mathrm{Vi}$ rol 79: 11533-11536. doi:10.1128/JVI.79.17.11533-11536 .2005

Gotoh B, Ogasawara T, Toyoda T, Inocencio NM, Hamaguchi M, Nagai Y. 1990. An endoprotease homologous to the blood clotting factor $\mathrm{X}$ as a determinant of viral tropism in chick embryo. EMBO J 9: 4189-4195. doi:10 $.1002 / j .1460-2075.1990 . t b 07643 . x$

Harris A, Cardone G, Winkler DC, Heymann JB, Brecher M, White JM, Steven AC. 2006. Influenza virus pleiomorphy characterized by cryoelectron tomography. Proc Natl Acad Sci 103: 19123-19127. doi:10.1073/pnas 0607614103

Henry Dunand CJ, Leon PE, Kaur K, Tan GS, Zheng NY, Andrews S, Huang M, Qu X, Huang Y, Salgado-Ferrer M, et al. 2015. Preexisting human antibodies neutralize recently emerged H7N9 influenza strains. J Clin Invest 125: 1255-1268. doi:10.1172/JCI74374

Henry Dunand CJ, Leon PE, Huang M, Choi A, Chromikova V, Ho IY, Tan GS, Cruz J, Hirsh A, Zheng NY, et al. 2016. Both neutralizing and non-neutralizing human H7N9 influenza vaccine-induced monoclonal antibodies confer protection. Cell Host Microbe 19: 800-813. doi:10.1016/j chom.2016.05.014

Hensley SE, Das SR, Bailey AL, Schmidt LM, Hickman HD, Jayaraman A, Viswanathan K, Raman R, Sasisekharan R Bennink JR, et al. 2009. Hemagglutinin receptor binding avidity drives influenza A virus antigenic drift. Science 326: 734-736. doi:10.1126/science.1178258

Herfst S, Schrauwen EJ, Linster M, Chutinimitkul S, de Wit E, Munster VJ, Sorrell EM, Bestebroer TM, Burke DF, Smith DJ, et al. 2012. Airborne transmission of influenza A/H5N1 virus between ferrets. Science 336: 1534-1541. doi:10.1126/science. 1213362

Hirst GK. 1942. The quantitative determination of influenza virus and antibodies by means of red cell agglutination. Exp Med 75: 49-64. doi:10.1084/jem.75.1.49

Hong M, Lee PS, Hoffman RM, Zhu X, Krause JC, Laursen NS, Yoon SI, Song L, Tussey L, Crowe JE Jr, et al. 2013. Antibody recognition of the pandemic H1N1 Influenza virus hemagglutinin receptor binding site. J Virol 87: 12471-12480. doi:10.1128/JVI.01388-13

Hutchinson EC, Charles PD, Hester SS, Thomas B, Trudgian D, Martínez-Alonso M, Fodor E. 2014. Conserved and host-specific features of influenza virion architecture. Nat Commun 5: 4816. doi:10.1038/ncomms5816 
N.C. Wu and I.A. Wilson

Iba Y, Fujii Y, Ohshima N, Sumida T, Kubota-Koketsu R, Ikeda M, Wakiyama M, Shirouzu M, Okada J, Okuno Y, et al. 2014. Conserved neutralizing epitope at globular head of hemagglutinin in H3N2 influenza viruses. J Virol 88: 7130-7144. doi:10.1128/JVI.00420-14

Igarashi M, Ito K, Kida H, Takada A. 2008. Genetically destined potentials for N-linked glycosylation of influenza virus hemagglutinin. Virology 376: 323-329. doi:10 $.1016 /$ j.virol.2008.03.036

Imai M, Watanabe T, Hatta M, Das SC, Ozawa M, Shinya K, Zhong G, Hanson A, Katsura H, Watanabe S, et al. 2012. Experimental adaptation of an influenza H5 HA confers respiratory droplet transmission to a reassortant $\mathrm{H} 5 \mathrm{HA} /$ H1N1 virus in ferrets. Nature 486: 420-428. doi:10.1038/ nature 10831

Impagliazzo A, Milder F, Kuipers H, Wagner MV, Zhu X, Hoffman RM, van Meersbergen R, Huizingh J, Wanningen P, Verspuij J, et al. 2015. A stable trimeric influenza hemagglutinin stem as a broadly protective immunogen. Science 349: 1301-1306. doi:10.1126/science.aac7263

Ito T, Suzuki Y, Takada A, Kawamoto A, Otsuki K, Masuda H, Yamada M, Suzuki T, Kida H, Kawaoka Y. 1997. Differences in sialic acid-galactose linkages in the chicken egg amnion and allantois influence human influenza virus receptor specificity and variant selection. J Virol $\mathbf{7 1}$ 3357-3362.

Jegaskanda S, Weinfurter JT, Friedrich TC, Kent SJ. 2013. Antibody-dependent cellular cytotoxicity is associated with control of pandemic H1N1 influenza virus infection of macaques. J Virol 87: 5512-5522. doi:10.1128/JVI .03030-12

Joyce MG, Wheatley AK, Thomas PV, Chuang GY, Soto C, Bailer RT, Druz A, Georgiev IS, Gillespie RA, Kanekiyo $\mathrm{M}$, et al. 2016. Vaccine-induced antibodies that neutralize group 1 and group 2 influenza A viruses. Cell 166: 609623. doi:10.1016/j.cell.2016.06.043

Kadam RU, Juraszek J, Brandenburg B, Buyck C, Schepens WBG, Kesteleyn B, Stoops B, Vreeken RJ, Vermond J, Goutier W, et al. 2017. Potent peptidic fusion inhibitors of influenza virus. Science 358: 496-502. doi:10.1126/sci ence.aan0516

Kallewaard NL, Corti D, Collins PJ, Neu U, McAuliffe JM, Benjamin E, Wachter-Rosati L, Palmer-Hill FJ, Yuan AQ, Walker PA, et al. 2016. Structure and function analysis of an antibody recognizing all influenza A subtypes. Cell 166: 596-608. doi:10.1016/j.cell.2016.05.073

Karakus U, Thamamongood T, Ciminski K, Ran W, Günther SC, Pohl MO, Eletto D, Jeney C, Hoffmann D, Reiche S, et al. 2019. MHC class II proteins mediate cross-species entry of bat influenza viruses. Nature 567: 109-112. doi:10.1038/s41586-019-0955-3

Kashyap AK, Steel J, Oner AF, Dillon MA, Swale RE, Wall KM, Perry KJ, Faynboym A, Ilhan M, Horowitz M, et al. 2008. Combinatorial antibody libraries from survivors of the Turkish H5N1 avian influenza outbreak reveal virus neutralization strategies. Proc Natl Acad Sci 105: 5986 5991. doi:10.1073/pnas.0801367105

Kashyap AK, Steel J, Rubrum A, Estelles A, Briante R, Ilyushina NA, Xu L, Swale RE, Faynboym AM, Foreman PK, et al. 2010. Protection from the 2009 H1N1 pandemic influenza by an antibody from combinatorial survivor- based libraries. PLoS Pathog 6: e1000990. doi:10.1371/ journal.ppat.1000990

Kido H, Yokogoshi Y, Sakai K, Tashiro M, Kishino Y, Fukutomi A, Katunuma N. 1992. Isolation and characterization of a novel trypsin-like protease found in rat bronchiolar epithelial Clara cells. A possible activator of the viral fusion glycoprotein. J Biol Chem 267: 13573-13579.

Kim JI, Lee I, Park S, Hwang MW, Bae JY, Lee S, Heo J, Park MS, García-Sastre A, Park MS. 2013. Genetic requirement for hemagglutinin glycosylation and its implications for influenza A H1N1 virus evolution. J Virol 87: 7539-7549. doi:10.1128/JVI.00373-13

Kirkpatrick E, Qiu X, Wilson PC, Bahl J, Krammer F. 2018. The influenza virus hemagglutinin head evolves faster than the stalk domain. Sci Rep 8: 10432. doi:10.1038/ s41598-018-28706-1

Kodihalli S, Justewicz DM, Gubareva LV, Webster RG. 1995. Selection of a single amino acid substitution in the hemagglutinin molecule by chicken eggs can render influenza A virus (H3) candidate vaccine ineffective. J Virol 69: 4888-4897.

Koel BF, Burke DF, Bestebroer TM, van der Vliet S, Zondag GC, Vervaet G, Skepner E, Lewis NS, Spronken MI, Russell CA, et al. 2013. Substitutions near the receptor binding site determine major antigenic change during influenza virus evolution. Science 342: 976-979. doi:10 $.1126 /$ science. 1244730

Korte T, Ludwig K, Huang Q, Rachakonda PS, Herrmann A. 2007. Conformational change of influenza virus hemagglutinin is sensitive to ionic concentration. Eur Biophys $J$ 36: 327-335. doi:10.1007/s00249-006-0116-0

Krause JC, Tsibane T, Tumpey TM, Huffman CJ, Basler CF, Crowe JE Jr. 2011. A broadly neutralizing human monoclonal antibody that recognizes a conserved, novel epitope on the globular head of the influenza H1N1 virus hemagglutinin. J Virol 85: 10905-10908. doi:10.1128/JVI .00700-11

Krause JC, Tsibane T, Tumpey TM, Huffman CJ, Albrecht R, Blum DL, Ramos I, Fernandez-Sesma A, Edwards KM, García-Sastre A, et al. 2012. Human monoclonal antibodies to pandemic $1957 \mathrm{H} 2 \mathrm{~N} 2$ and pandemic $1968 \mathrm{H} 3 \mathrm{~N} 2$ influenza viruses. J Virol 86: 6334-6340. doi:10.1128/JVI .07158-11

Lang S, Xie J, Zhu X, Wu NC, Lerner RA, Wilson IA. 2017. Antibody 27F3 broadly targets influenza A group 1 and 2 hemagglutinins through a further variation in $\mathrm{V}_{\mathrm{H}} 1-69$ antibody orientation on the HA stem. Cell Rep 20: 2935-2943. doi:10.1016/j.celrep.2017.08.084

Laursen NS, Friesen RHE, Zhu X, Jongeneelen M, Blokland S, Vermond J, van Eijgen A, Tang C, van Diepen $\mathrm{H}$, Obmolova G, et al. 2018. Universal protection against influenza infection by a multidomain antibody to influenza hemagglutinin. Science 362: 598-602. doi:10.1126/ science.aaq0620

Lazarowitz SG, Choppin PW. 1975. Enhancement of the infectivity of influenza A and B viruses by proteolytic cleavage of the hemagglutinin polypeptide. Virology 68: 440-454. doi:10.1016/0042-6822(75)90285-8

Lee PS, Wilson IA. 2015. Structural characterization of viral epitopes recognized by broadly cross-reactive antibodies. Curr Top Microbiol Immunol 386: 323-341. doi: 10.1007/ 82_2014_413 
Lee PS, Yoshida R, Ekiert DC, Sakai N, Suzuki Y, Takada A, Wilson IA. 2012. Heterosubtypic antibody recognition of the influenza virus hemagglutinin receptor binding site enhanced by avidity. Proc Natl Acad Sci 109: 1704017045. doi:10.1073/pnas.1212371109

Lee PS, Ohshima N, Stanfield RL, Yu W, Iba Y, Okuno Y, Kurosawa Y, Wilson IA. 2014. Receptor mimicry by antibody F045-092 facilitates universal binding to the H3 subtype of influenza virus. Nat Commun 5: 3614 . doi:10 $.1038 /$ ncomms 4614

Lee J, Boutz DR, Chromikova V, Joyce MG, Vollmers C, Leung K, Horton AP, DeKosky BJ, Lee CH, Lavinder JJ, et al. 2016. Molecular-level analysis of the serum antibody repertoire in young adults before and after seasonal influenza vaccination. Nat Med 22: 1456-1464. doi:10.1038/ nm. 4224

Li J, Wang Y, Liang Y, Ni B, Wan Y, Liao Z, Chan KH, Yuen KY, Fu X, Shang X, et al. 2009. Fine antigenic variation within $\mathrm{H} 5 \mathrm{~N} 1$ influenza virus hemagglutinin's antigenic sites defined by yeast cell surface display. Eur J Immunol 39: 3498-3510. doi:10.1002/eji.200939532

Li Y, Bostick DL, Sullivan CB, Myers JL, Griesemer SB, Stgeorge K, Plotkin JB, Hensley SE. 2013. Single hemagglutinin mutations that alter both antigenicity and receptor binding avidity influence influenza virus antigenic clustering. J Virol 87: 9904-9910. doi:10.1128/JVI .01023-13

Lin YP, Xiong X, Wharton SA, Martin SR, Coombs PJ, Vachieri SG, Christodoulou E, Walker PA, Liu J, Skehel JJ, et al. 2012. Evolution of the receptor binding properties of the influenza A(H3N2) hemagglutinin. Proc Natl Acad Sci 109: 21474-21479. doi:10.1073/pnas.1218841110

Lowen AC. 2017. Constraints, drivers, and implications of influenza A virus reassortment. Annu Rev Virol 4: 105121. doi:10.1146/annurev-virology-101416-041726

Lu X, Shi Y, Zhang W, Zhang Y, Qi J, Gao GF. 2013. Structure and receptor-binding properties of an airborne transmissible avian influenza A virus hemagglutinin H5 (VN1203mut). Protein Cell 4: 502-511. doi:10.1007/ s13238-013-3906-z

Maeda T, Ohnishi S. 1980. Activation of influenza virus by acidic media causes hemolysis and fusion of erythrocytes. FEBS Lett 122: 283-287. doi:10.1016/0014-5793(80) 80457-1

Mair CM, Meyer T, Schneider K, Huang Q, Veit M, Herrmann A. 2014. A histidine residue of the influenza virus hemagglutinin controls the $\mathrm{pH}$ dependence of the conformational change mediating membrane fusion. J Virol 88: 13189-13200. doi:10.1128/JVI.01704-14

Mallajosyula VV, Citron M, Ferrara F, Lu X, Callahan C, Heidecker GJ, Sarma SP, Flynn JA, Temperton NJ, Liang $\mathrm{X}$, et al. 2014. Influenza hemagglutinin stem-fragment immunogen elicits broadly neutralizing antibodies and confers heterologous protection. Proc Natl Acad Sci 111: E2514-E2523. doi:10.1073/pnas.1402766111

Mallajosyula VV, Citron M, Ferrara F, Temperton NJ, Liang X, Flynn JA, Varadarajan R. 2015. Hemagglutinin sequence conservation guided stem immunogen design from influenza A H3 subtype. Front Immunol 6: 329. doi:10.3389/fimmu.2015.00329

Matrosovich MN, Gambaryan AS, Teneberg S, Piskarev VE, Yamnikova SS, Lvov DK, Robertson JS, Karlsson
KA. 1997. Avian influenza A viruses differ from human viruses by recognition of sialyloligosaccharides and gangliosides and by a higher conservation of the HA receptor-binding site. Virology 233: 224-234. doi:10.1006/ viro.1997.8580

McCarthy KR, Watanabe A, Kuraoka M, Do KT, McGee CE, Sempowski GD, Kepler TB, Schmidt AG, Kelsoe G, Harrison SC. 2018. Memory B cells that cross-react with group 1 and group 2 influenza $A$ viruses are abundant in adult human repertoires. Immunity 48: 174-184.e9. doi:10.1016/j.immuni.2017.12.009

Nakamura G, Chai N, Park S, Chiang N, Lin Z, Chiu H, Fong R, Yan D, Kim J, Zhang J, et al. 2013. An in vivo humanplasmablast enrichment technique allows rapid identification of therapeutic influenza A antibodies. Cell Host Microbe 14: 93-103. doi:10.1016/j.chom.2013.06.004

Nogales E. 2016. The development of cryo-EM into a mainstream structural biology technique. Nat Methods 13: 2427. doi:10.1038/nmeth.3694

Ohshima N, Iba Y, Kubota-Koketsu R, Asano Y, Okuno Y, Kurosawa Y. 2011. Naturally occurring antibodies in humans can neutralize a variety of influenza virus strains, including H3, H1, H2, and H5. J Virol 85: 11048-11057. doi:10.1128/JVI.05397-11

Okuno Y, Isegawa Y, Sasao F, Ueda S. 1993. A common neutralizing epitope conserved between the hemagglutinins of influenza A virus $\mathrm{H} 1$ and $\mathrm{H} 2$ strains. J Virol 67: 2552-2558.

Pappas C, Viswanathan K, Chandrasekaran A, Raman R, Katz JM, Sasisekharan R, Tumpey TM. 2010. Receptor specificity and transmission of $\mathrm{H} 2 \mathrm{~N} 2$ subtype viruses isolated from the pandemic of 1957. PLoS ONE 5: e11158. doi:10.1371/journal.pone.0011158

Parker L, Wharton SA, Martin SR, Cross K, Lin Y, Liu Y, Feizi T, Daniels RS, McCauley JW. 2016. Effects of eggadaptation on receptor-binding and antigenic properties of recent influenza A (H3N2) vaccine viruses. J Gen Virol 97: 1333-1344. doi:10.1099/jgv.0.000457

Peng W, de Vries RP, Grant OC, Thompson AJ, McBride R, Tsogtbaatar B, Lee PS, Razi N, Wilson IA, Woods RJ, et al. 2017. Recent H3N2 viruses have evolved specificity for extended, branched human-type receptors, conferring potential for increased avidity. Cell Host Microbe 21: 23-34. doi:10.1016/j.chom.2016.11.004

Popova L, Smith K, West AH, Wilson PC, James JA, Thompson LF, Air GM. 2012. Immunodominance of antigenic site B over site A of hemagglutinin of recent $\mathrm{H} 3 \mathrm{~N} 2$ influenza viruses. PLoS ONE 7: e41895. doi:10.1371/journal .pone.0041895

Puri A, Booy FP, Doms RW, White JM, Blumenthal R. 1990. Conformational changes and fusion activity of influenza virus hemagglutinin of the $\mathrm{H} 2$ and $\mathrm{H} 3$ subtypes: effects of acid pretreatment. J Virol 64: 3824-3832.

Rachakonda PS, Veit M, Korte T, Ludwig K, Böttcher C, Huang Q, Schmidt MF, Herrmann A. 2007. The relevance of salt bridges for the stability of the influenza virus hemagglutinin. FASEB J 21: 995-1002. doi:10.1096/fj.067052hyp

Raymond DD, Stewart SM, Lee J, Ferdman J, Bajic G, Do KT, Ernandes MJ, Suphaphiphat P, Settembre EC, Dormitzer PR, et al. 2016. Influenza immunization elicits antibodies 
N.C. Wu and I.A. Wilson

specific for an egg-adapted vaccine strain. Nat Med 22 1465-1469. doi:10.1038/nm.4223

Raymond DD, Bajic G, Ferdman J, Suphaphiphat P, Settembre EC, Moody MA, Schmidt AG, Harrison SC. 2018 Conserved epitope on influenza-virus hemagglutinin head defined by a vaccine-induced antibody. Proc Natl Acad Sci 115: 168-173. doi:10.1073/pnas.1715471115

Roberts KL, Shelton H, Scull M, Pickles R, Barclay WS. 2011. Lack of transmission of a human influenza virus with avian receptor specificity between ferrets is not due to decreased virus shedding but rather a lower infectivity in vivo. J Gen Virol 92: 1822-1831. doi:10.1099/vir.0 .031203-0

Robertson JS, Bootman JS, Newman R, Oxford JS, Daniels RS, Webster RG, Schild GC. 1987. Structural changes in the haemagglutinin which accompany egg adaptation of an influenza A(H1N1) virus. Virology 160: 31-37. doi:10 .1016/0042-6822(87)90040-7

Rogers GN, Paulson JC, Daniels RS, Skehel JJ, Wilson IA Wiley DC. 1983. Single amino acid substitutions in influenza haemagglutinin change receptor binding specificity. Nature 304: 76-78. doi:10.1038/304076a0

Sabesan S, Bock K, Paulson JC. 1991. Conformational analysis of sialyloligosaccharides. Carbohydr Res 218: 27-54. doi:10.1016/0008-6215(91)84084-R

Schmidt AG, Xu H, Khan AR, O’Donnell T, Khurana S, King LR, Manischewitz J, Golding H, Suphaphiphat P, Carfi A, et al. 2013. Preconfiguration of the antigen-binding site during affinity maturation of a broadly neutralizing influenza virus antibody. Proc Natl Acad Sci 110: 264-269. doi:10.1073/pnas.1218256109

Schmidt AG, Therkelsen MD, Stewart S, Kepler TB, Liao HX, Moody MA, Haynes BF, Harrison SC. 2015. Viral receptor-binding site antibodies with diverse germline origins. Cell 161: 1026-1034. doi:10.1016/j.cell.2015.04 .028

Scholtissek C. 1985. Stability of infectious influenza A viruses at low $\mathrm{pH}$ and at elevated temperature. Vaccine 3: 215 218. doi:10.1016/0264-410X(85)90109-4

Shi Y, Wu Y, Zhang W, Qi J, Gao GF. 2014. Enabling the "host jump": structural determinants of receptor-binding specificity in influenza A viruses. Nat Rev Microbiol 12: 822-831. doi:10.1038/nrmicro3362

Simmonds P, Zhang LQ, McOmish F, Balfe P, Ludlam CA Brown AJ. 1991. Discontinuous sequence change of human immunodeficiency virus (HIV) type 1 env sequences in plasma viral and lymphocyte-associated proviral populations in vivo: implications for models of HIV pathogenesis. J Virol 65: 6266-6276.

Skehel JJ, Stevens DJ, Daniels RS, Douglas AR, Knossow M, Wilson IA, Wiley DC. 1984. A carbohydrate side chain on hemagglutinins of Hong Kong influenza viruses inhibits recognition by a monoclonal antibody. Proc Natl Acad Sci 81: 1779-1783. doi:10.1073/pnas.81.6.1779

Smith DJ, Lapedes AS, de Jong JC, Bestebroer TM, Rimmelzwaan GF, Osterhaus AD, Fouchier RA. 2004. Mapping the antigenic and genetic evolution of influenza virus. Science 305: 371-376. doi:10.1126/science.1097211

Song H, Qi J, Xiao H, Bi Y, Zhang W, Xu Y, Wang F, Shi Y, Gao GF. 2017. Avian-to-human receptor-binding adaptation by influenza A virus hemagglutinin H4. Cell Rep 20: 1201-1214. doi:10.1016/j.celrep.2017.07.028
Sriwilaijaroen N, Kondo S, Yagi H, Wilairat P, Hiramatsu H, Ito M, Ito Y, Kato K, Suzuki Y. 2009. Analysis of Nglycans in embryonated chicken egg chorioallantoic and amniotic cells responsible for binding and adaptation of human and avian influenza viruses. Glycoconj J 26: 433443. doi:10.1007/s10719-008-9193-x

Steel J, Lowen AC, Wang TT, Yondola M, Gao Q, Haye K, García-Sastre A, Palese P. 2010. Influenza virus vaccine based on the conserved hemagglutinin stalk domain. mBio 1: e00018-e00010. doi:10.1128/mBio.00018-10

Stevens J, Blixt O, Glaser L, Taubenberger JK, Palese P, Paulson JC, Wilson IA. 2006. Glycan microarray analysis of the hemagglutinins from modern and pandemic influenza viruses reveals different receptor specificities. J Mol Biol 355: 1143-1155. doi:10.1016/j.jmb.2005.11.002

Stone JD. 1948. Prevention of virus infection with enzyme of $V$. cholerae. II: studies with influenza virus in mice. Aust $J$ Exp Biol Med Sci 26: 287-298. doi:10.1038/icb.1948.30

Strauch EM, Bernard SM, La D, Bohn AJ, Lee PS, Anderson CE, Nieusma T, Holstein CA, Garcia NK, Hooper KA, et al. 2017. Computational design of trimeric influenzaneutralizing proteins targeting the hemagglutinin receptor binding site. Nat Biotechnol 35: 667-671. doi:10.1038/ nbt. 3907

Suarez DL, Garcia M, Latimer J, Senne D, Perdue M. 1999. Phylogenetic analysis of $\mathrm{H} 7$ avian influenza viruses isolated from the live bird markets of the Northeast United States. J Virol 73: 3567-3573.

Sui J, Hwang WC, Perez S, Wei G, Aird D, Chen LM, Santelli E, Stec B, Cadwell G, Ali M, et al. 2009. Structural and functional bases for broad-spectrum neutralization of avian and human influenza A viruses. Nat Struct Mol Biol 16: 265-273. doi:10.1038/nsmb.1566

Sun S, Wang Q, Zhao F, Chen W, Li Z. 2011. Glycosylation site alteration in the evolution of influenza A (H1N1) viruses. PLOS ONE 6: e22844. doi:10.1371/journal.pone .0022844

Sun X, Shi Y, Lu X, He J, Gao F, Yan J, Qi J, Gao GF. 2013. Bat-derived influenza hemagglutinin $\mathrm{H} 17$ does not bind canonical avian or human receptors and most likely uses a unique entry mechanism. Cell Rep 3: 769-778. doi:10 $.1016 /$ j.celrep.2013.01.025

Tan HX, Jegaskanda S, Juno JA, Esterbauer R, Wong J, Kelly HG, Liu Y, Tilmanis D, Hurt AC, Yewdell JW, et al. 2019. Subdominance and poor intrinsic immunogenicity limit humoral immunity targeting influenza HA stem. J Clin Invest 129: 850-862. doi:10.1172/JCI123366

Tate MD, Job ER, Deng YM, Gunalan V, Maurer-Stroh S, Reading PC. 2014. Playing hide and seek: how glycosylation of the influenza virus hemagglutinin can modulate the immune response to infection. Viruses 6: 1294-1316. doi:10.3390/v6031294

Thoennes S, Li ZN, Lee BJ, Langley WA, Skehel JJ, Russell RJ, Steinhauer DA. 2008. Analysis of residues near the fusion peptide in the influenza hemagglutinin structure for roles in triggering membrane fusion. Virology 370: 403-414. doi:10.1016/j.virol.2007.08.035

Thornburg NJ, Zhang H, Bangaru S, Sapparapu G, Kose N, Lampley RM, Bombardi RG, Yu Y, Graham S, Branchizio A, et al. 2016. H7N9 influenza virus neutralizing antibodies that possess few somatic mutations. J Clin Invest 126: 1482-1494. doi:10.1172/JCI85317 
Throsby M, van den Brink E, Jongeneelen M, Poon LL, Alard P, Cornelissen L, Bakker A, Cox F, van Deventer E, Guan Y, et al. 2008. Heterosubtypic neutralizing monoclonal antibodies cross-protective against $\mathrm{H} 5 \mathrm{~N} 1$ and $\mathrm{H} 1 \mathrm{~N} 1$ recovered from human IgM $\mathrm{I}^{+}$memory B cells. PLoS ONE 3: e3942. doi:10.1371/journal.pone.0003942

Tong S, Zhu X, Li Y, Shi M, Zhang J, Bourgeois M, Yang H, Chen X, Recuenco S, Gomez J, et al. 2013. New world bats harbor diverse influenza A viruses. PLoS Pathog 9: e1003657. doi:10.1371/journal.ppat.1003657

Tricco AC, Chit A, Soobiah C, Hallett D, Meier G, Chen MH, Tashkandi M, Bauch CT, Loeb M. 2013. Comparing influenza vaccine efficacy against mismatched and matched strains: a systematic review and meta-analysis. BMC Med 11: 153. doi:10.1186/1741-7015-11-153

Tsibane T, Ekiert DC, Krause JC, Martinez O, Crowe JE Jr, Wilson IA, Basler CF. 2012. Influenza human monoclonal antibody $1 \mathrm{~F} 1$ interacts with three major antigenic sites and residues mediating human receptor specificity in H1N1 viruses. PLoS Pathog 8: e1003067. doi:10.1371/jour nal.ppat.1003067

Tsuchiya E, Sugawara K, Hongo S, Matsuzaki Y, Muraki Y, Li ZN, Nakamura K. 2001. Antigenic structure of the haemagglutinin of human influenza A/H2N2 virus. J Gen Virol 82: 2475-2484. doi:10.1099/0022-1317-82-10-2475

Tsuchiya E, Sugawara K, Hongo S, Matsuzaki Y, Muraki Y, Li ZN, Nakamura K. 2002. Effect of addition of new oligosaccharide chains to the globular head of influenza $\mathrm{A} /$ $\mathrm{H} 2 \mathrm{~N} 2$ virus haemagglutinin on the intracellular transport and biological activities of the molecule. J Gen Virol 83: 1137-1146. doi:10.1099/0022-1317-83-5-1137

Tumpey TM, Maines TR, Van Hoeven N, Glaser L, Solorzano A, Pappas C, Cox NJ, Swayne DE, Palese P, Katz JM, et al. 2007. A two-amino acid change in the hemagglutinin of the 1918 influenza virus abolishes transmission. Science 315: 655-659. doi:10.1126/science .1136212

Turner HL, Pallesen J, Lang S, Bangaru S, Urata S, Li S, Cottrell CA, Bowman CA, Crowe JE Jr, Wilson IA, et al. 2019. Potent anti-influenza H7 human monoclonal antibody induces separation of hemagglutinin receptor-binding head domains. PLoS Biol 17: e3000139. doi:10.1371/ journal.pbio.3000139

Tzarum N, de Vries RP, Peng W, Thompson AJ, Bouwman KM, McBride R, Yu W, Zhu X, Verheije MH, Paulson JC, et al. 2017. The 150-loop restricts the host specificity of human H10N8 influenza virus. Cell Rep 19: 235-245. doi:10.1016/j.celrep.2017.03.054

Valkenburg SA, Mallajosyula VV, Li OT, Chin AW, Carnell G, Temperton N, Varadarajan R, Poon LL. 2016. Stalking influenza by vaccination with pre-fusion headless HA mini-stem. Sci Rep 6: 22666. doi:10.1038/srep22666

van Dongen MJP, Kadam RU, Juraszek J, Lawson E, Brandenburg B, Schmitz F, Schepens WBG, Stoops B, van Diepen HA, Jongeneelen M, et al. 2019. A small-molecule fusion inhibitor of influenza virus is orally active in mice. Science 363: eaar6221. doi: 10.1126/science.aar6221

Wang ML, Skehel JJ, Wiley DC. 1986. Comparative analyses of the specificities of anti-influenza hemagglutinin antibodies in human sera. J Virol 57: 124-128.

Wang Q, Tian X, Chen X, Ma J. 2007. Structural basis for receptor specificity of influenza $\mathrm{B}$ virus hemagglutinin.
Proc Natl Acad Sci 104: 16874-16879. doi:10.1073/pnas 0708363104

Watanabe A, McCarthy KR, Kuraoka M, Schmidt AG, Adachi Y, Onodera T, Tonouchi K, Caradonna TM, Bajic G, Song S, et al. 2019. Antibodies to a conserved influenza head interface epitope protect by an IgG subtype-dependent mechanism. Cell 177: 1124-1135.e16. doi:10.1016/j .cell.2019.03.048

Weis W, Brown JH, Cusack S, Paulson JC, Skehel JJ, Wiley DC. 1988. Structure of the influenza virus haemagglutinin complexed with its receptor, sialic acid. Nature 333: 426431. doi:10.1038/333426a0

Whitehead TA, Chevalier A, Song Y, Dreyfus C, Fleishman SJ, De Mattos C, Myers CA, Kamisetty H, Blair P, Wilson IA, et al. 2012. Optimization of affinity, specificity and function of designed influenza inhibitors using deep sequencing. Nat Biotechnol 30: 543-548. doi:10.1038/nbt .2214

Whittle JR, Zhang R, Khurana S, King LR, Manischewitz J, Golding H, Dormitzer PR, Haynes BF, Walter EB, Moody MA, et al. 2011. Broadly neutralizing human antibody that recognizes the receptor-binding pocket of influenza virus hemagglutinin. Proc Natl Acad Sci 108: 1421614221. doi:10.1073/pnas.1111497108

Wiley DC, Skehel JJ. 1987. The structure and function of the hemagglutinin membrane glycoprotein of influenza virus. Annu Rev Biochem 56: 365-394. doi:10.1146/an nurev.bi.56.070187.002053

Wiley DC, Wilson IA, Skehel JJ. 1981. Structural identification of the antibody-binding sites of Hong Kong influenza haemagglutinin and their involvement in antigenic variation. Nature 289: 373-378. doi:10.1038/289373a0

Wilson IA, Skehel JJ, Wiley DC. 1981. Structure of the haemagglutinin membrane glycoprotein of influenza virus at $3 \AA$ resolution. Nature 289: 366-373. doi:10.1038/ 289366a 0

Wilson IA, Niman HL, Houghten RA, Cherenson AR, Connolly ML, Lerner RA. 1984. The structure of an antigenic determinant in a protein. Cell 37: 767-778. doi:10.1016/ 0092-8674(84)90412-4

Wohlbold TJ, Nachbagauer R, Margine I, Tan GS, Hirsh A, Krammer F. 2015. Vaccination with soluble headless hemagglutinin protects mice from challenge with divergent influenza viruses. Vaccine 33: 3314-3321. doi:10 $.1016 /$ j.vaccine.2015.05.038

Wrammert J, Smith K, Miller J, Langley WA, Kokko K, Larsen C, Zheng NY, Mays I, Garman L, Helms C, et al. 2008. Rapid cloning of high-affinity human monoclonal antibodies against influenza virus. Nature 453: 667-671. doi:10.1038/nature06890

Wu NC, Wilson IA. 2017. A perspective on the structural and functional constraints for immune evasion: insights from influenza virus. J Mol Biol 429: 2694-2709. doi:10 $.1016 /$ j.jmb.2017.06.015

Wu NC, Wilson IA. 2018. Structural insights into the design of novel anti-influenza therapies. Nat Struct Mol Biol 25: 115-121. doi:10.1038/s41594-018-0025-9

Wu Y, Cho M, Shore D, Song M, Choi J, Jiang T, Deng YQ, Bourgeois M, Almli L, Yang H, et al. 2015. A potent broad-spectrum protective human monoclonal antibody crosslinking two haemagglutinin monomers of influenza A virus. Nat Commun 6: 7708. doi:10.1038/ncomms8708 
N.C. Wu and I.A. Wilson

Wu NC, Zost SJ, Thompson AJ, Oyen D, Nycholat CM McBride R, Paulson JC, Hensley SE, Wilson IA. 2017. A structural explanation for the low effectiveness of the seasonal influenza H3N2 vaccine. PLoS Pathog 13: e1006682. doi:10.1371/journal.ppat.1006682

Wu NC, Thompson AJ, Xie J, Lin CW, Nycholat CM, Zhu X, Lerner RA, Paulson JC, Wilson IA. 2018a. A complex epistatic network limits the mutational reversibility in the influenza hemagglutinin receptor-binding site. Nat Commun 9: 1264. doi:10.1038/s41467-018-03663-5

Wu NC, Yamayoshi S, Ito M, Uraki R, Kawaoka Y, Wilson IA. 2018b. Recurring and adaptable binding motifs in broadly neutralizing antibodies to influenza virus are encoded on the D3-9 segment of the Ig gene. Cell Host Microbe 24: 569-578.e4. doi:10.1016/j.chom.2018.09.010

Wu NC, Lv H, Thompson AJ, Wu DC, Ng WWS, Kadam RU, Lin CW, Nycholat CM, McBride R, Liang W, et al. 2019. Preventing an antigenically disruptive mutation in egg-based H3N2 seasonal influenza vaccines by mutational incompatibility. Cell Host Microbe 25: 836-844. e5. doi:10.1016/j.chom.2019.04.013

Xiong X, Coombs PJ, Martin SR, Liu J, Xiao H, McCauley JW, Locher K, Walker PA, Collins PJ, Kawaoka Y, et al. 2013. Receptor binding by a ferret-transmissible $\mathrm{H} 5$ avian influenza virus. Nature 497: 392-396. doi:10.1038/na ture 12144

$\mathrm{Xu}$ R, Wilson IA. 2011. Structural characterization of an early fusion intermediate of influenza virus hemagglutinin. J Virol 85: 5172-5182. doi:10.1128/JVI.02430-10

Xu R, McBride R, Paulson JC, Basler CF, Wilson IA. 2010. Structure, receptor binding, and antigenicity of influenza virus hemagglutinins from the $1957 \mathrm{H} 2 \mathrm{~N} 2$ pandemic. $J$ Virol 84: 1715-1721. doi:10.1128/JVI.02162-09

Xu R, McBride R, Nycholat CM, Paulson JC, Wilson IA 2012. Structural characterization of the hemagglutinin receptor specificity from the $2009 \mathrm{H} 1 \mathrm{~N} 1$ influenza pandemic. J Virol 86: 982-990. doi:10.1128/JVI.06322-11

Xu R, Krause JC, McBride R, Paulson JC, Crowe JE Jr, Wilson IA. 2013. A recurring motif for antibody recognition of the receptor-binding site of influenza hemagglutinin. Nat Struct Mol Biol 20: 363-370. doi:10.1038/nsmb.2500

Yamayoshi S, Uraki R, Ito M, Kiso M, Nakatsu S, Yasuhara A, Oishi K, Sasaki T, Ikuta K, Kawaoka Y. 2017. A broadly reactive human anti-hemagglutinin stem monoclonal antibody that inhibits influenza A virus particle release. EBioMedicine 17: 182-191. doi:10.1016/j.ebiom.2017.03 .007

Yang H, Chen LM, Carney PJ, Donis RO, Stevens J. 2010. Structures of receptor complexes of a North American $\mathrm{H} 7 \mathrm{~N} 2$ influenza hemagglutinin with a loop deletion in the receptor binding site. PLoS Pathog 6: e1001081. doi:10.1371/journal.ppat.1001081

Yassine HM, Boyington JC, McTamney PM, Wei CJ, Kanekiyo M, Kong WP, Gallagher JR, Wang L, Zhang Y, Joyce MG, et al. 2015. Hemagglutinin-stem nanoparticles generate heterosubtypic influenza protection. Nat Med 21: 1065-1070. doi:10.1038/nm.3927

Yasugi M, Kubota-Koketsu R, Yamashita A, Kawashita N, Du A, Sasaki T, Nishimura M, Misaki R, Kuhara M, Boonsathorn N, et al. 2013. Human monoclonal antibodies broadly neutralizing against influenza B virus. PLoS Pathog 9: e1003150. doi:10.1371/journal.ppat.1003150

Yoshida R, Igarashi M, Ozaki H, Kishida N, Tomabechi D, Kida H, Ito K, Takada A. 2009. Cross-protective potential of a novel monoclonal antibody directed against antigenic site B of the hemagglutinin of influenza A viruses. PLoS Pathog 5: e1000350. doi:10.1371/journal.ppat.1000350

Zhang M, Gaschen B, Blay W, Foley B, Haigwood N, Kuiken C, Korber B. 2004. Tracking global patterns of N-linked glycosylation site variation in highly variable viral glycoproteins: HIV, SIV, and HCV envelopes and influenza hemagglutinin. Glycobiology 14: 1229-1246. doi:10 .1093/glycob/cwh106

Zhu X, Guo YH, Jiang T, Wang YD, Chan KH, Li XF, Yu W, McBride R, Paulson JC, Yuen KY, et al. 2013a. A unique and conserved neutralization epitope in $\mathrm{H} 5 \mathrm{~N} 1$ influenza viruses identified by an antibody against the A/Goose/ Guangdong/1/96 hemagglutinin. J Virol 87: 1261912635. doi:10.1128/JVI.01577-13

Zhu X, Yu W, McBride R, Li Y, Chen LM, Donis RO, Tong S, Paulson JC, Wilson IA. 2013b. Hemagglutinin homologue from $\mathrm{H} 17 \mathrm{~N} 10$ bat influenza virus exhibits divergent receptor-binding and $\mathrm{pH}$-dependent fusion activities. Proc Natl Acad Sci 110: 1458-1463. doi:10.1073/pnas .1218509110

Zost SJ, Parkhouse K, Gumina ME, Kim K, Diaz Perez S, Wilson PC, Treanor JJ, Sant AJ, Cobey S, Hensley SE. 2017. Contemporary H3N2 influenza viruses have a glycosylation site that alters binding of antibodies elicited by egg-adapted vaccine strains. Proc Natl Acad Sci 114: 12578-12583. doi:10.1073/pnas.1712377114

Zost SJ, Wu NC, Hensley SE, Wilson IA. 2019. Immunodominance and antigenic variation of influenza virus hemagglutinin: implications for design of universal vaccine immunogens. J Infect Dis 219: S38-S45. doi:10.1093/ infdis/jiy696

Zuo T, Sun J, Wang G, Jiang L, Zuo Y, Li D, Shi X, Liu X, Fan S, Ren H, et al. 2015. Comprehensive analysis of antibody recognition in convalescent humans from highly pathogenic avian influenza H5N1 infection. Nat Commun 6: 8855. doi:10.1038/ncomms9855 


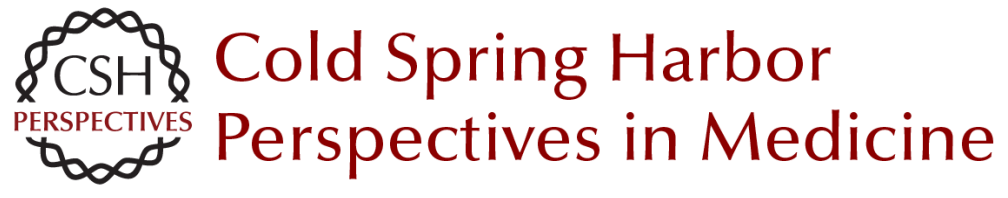

\section{Influenza Hemagglutinin Structures and Antibody Recognition}

Nicholas C. Wu and lan A. Wilson

Cold Spring Harb Perspect Med 2020; doi: 10.1101/cshperspect.a038778 originally published online December 23, 2019

Subject Collection Influenza: The Cutting Edge

\section{Emerging HxNy Influenza A Viruses William J. Liu, Yan Wu, Yuhai Bi, et al. \\ Equine Influenza Thomas M. Chambers \\ Human Influenza Epidemiology Sukhyun Ryu and Benjamin J. Cowling}

Host Cell Factors That Interact with Influenza Virus Ribonucleoproteins Ecco Staller and Wendy S. Barclay Induction and Evasion of Type-I Interferon Responses during Influenza A Virus Infection Raquel Muñoz-Moreno, Carles Martínez-Romero and Adolfo García-Sastre

Structure and Function of Influenza Polymerase Joanna M. Wandzik, Tomas Kouba and Stephen Cusack

H7N9 Influenza Virus in China Chengjun Li and Hualan Chen

H5 Influenza Viruses in Egypt Rabeh El-Shesheny, Ahmed Kandeil, Ahmed Mostafa, et al. Antivirals Targeting the Neuraminidase
Larisa Gubareva and Teena Mohan

Accessory Gene Products of Influenza A Virus Rute M. Pinto, Samantha Lycett, Eleanor Gaunt, et al.

Influenza Immunization in the Context of

Preexisting Immunity Susanne L. Linderman, Ali H. Ellebedy, Carl Davis, et al.

Hemagglutinin Structure and Activities Steven J. Gamblin, Sébastien G. Vachieri, Xiaoli Xiong, et al.

Live Attenuated Cold-Adapted Influenza Vaccines Kanta Subbarao

Next-Generation Influenza Vaccines Masaru Kanekiyo and Barney S. Graham

\section{Selective Genome Packaging Mechanisms of Influenza A Viruses Takeshi Noda}

Systems Biological Analysis of Immune Response to Influenza Vaccination Mario Cortese, Amy C. Sherman, Nadine G. Rouphael, et al.

For additional articles in this collection, see http://perspectivesinmedicine.cshlp.org/cgi/collection/ 